\title{
7300 years of vegetation history and climate for NW Malta: a Holocene perspective
}

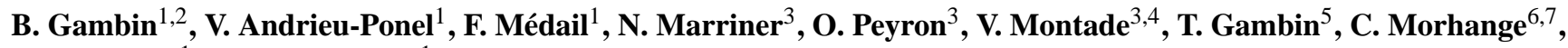 \\ D. Belkacem ${ }^{1}$, and M. Djamali ${ }^{1}$
}

${ }^{1}$ Institut Méditerranéen de Biodiversité et d'Ecologie marine et continentale (IMBE), Aix Marseille Université, CNRS, IRD, Avignon Université, Bâtiment Villemin, BP 80, 13545 Aix-en-Provence CEDEX 04, France

${ }^{2}$ Institute of Earth Systems, University of Malta, Msida, MSD 2080, Malta

${ }^{3}$ Institut des Sciences de l'Evolution de Montpellier, UM, CNRS, IRD EPHE, Avenue Eugène Bataillon, 34095 Montpellier CEDEX 05, France

${ }^{4}$ Ecole Pratique des Hautes Etudes, 4-14 rue Ferrus, 75014 Paris, France

${ }^{5}$ Department of Classics and Archaeology, University of Malta, Msida, MSD 2080, Malta

${ }^{6}$ CEREGE, Aix Marseille Université, CNRS, BP 80, 13545 Aix-en-Provence CEDEX 04, France

${ }^{7}$ Institut Universitaire de France, Paris, France

Correspondence to: B. Gambin (belinda.gambin@imbe.fr; belinda.gambin@um.edu.mt)

Received: 28 August 2015 - Published in Clim. Past Discuss.: 30 September 2015

Revised: 18 January 2016 - Accepted: 18 January 2016 - Published: 15 February 2016

\begin{abstract}
This paper investigates the Holocene vegetation dynamics for Burmarrad in Northwest Malta and provides a pollen-based quantitative palaeoclimatic reconstruction for this centrally located Mediterranean archipelago. The pollen record from this site provides new insight into the vegetation changes from 7280 to $1730 \mathrm{cal} \mathrm{BP}$ which correspond well with other regional records. The climate reconstruction for the area also provides strong correlation with southern (below $40^{\circ} \mathrm{N}$ ) Mediterranean sites. Our interpretation suggests an initially open landscape during the early Neolithic, surrounding a large palaeobay, developing into a dense Pistacia scrubland ca. $6700 \mathrm{cal} \mathrm{BP}$. From about $4450 \mathrm{cal} \mathrm{BP}$ the landscape once again becomes open, coinciding with the start of the Bronze Age on the archipelago. This period is concurrent with increased climatic instability (between 4500 and 3700 cal BP) which is followed by a gradual decrease in summer moisture availability in the late Holocene. During the early Roman occupation period (1972-1730 cal BP) the landscape remains generally open with a moderate increase in Olea. This increase corresponds to archaeological evidence for olive oil production in the area, along with increases in cultivated crop taxa and associated ruderal species, as well as a rise in fire events. The Maltese archipelago provides im-
\end{abstract}

portant insight into vegetation, human impacts, and climatic changes in an island context during the Holocene.

\section{Introduction}

Interpreting the complex relationship between vegetation dynamics, climate change, and anthropogenic activities during the Holocene is important for understanding past societies and their environment (Weiner, 2010; Walsh, 2013). Palynology, the study of pollen and spores (e.g. Erdtman, 1943; Faegri and Iversen, 2000; Moore et al., 1991; Traverse, 2008), has been an important element in this interpretation and has been central to environmental reconstruction since the early 20th century (MacDonald and Edwards, 1991). The analysis of pollen grains extracted from sediment cores from terrestrial and marine environments, as part of an interdisciplinary approach, provides quantitative data on the past changes in vegetation compositions (e.g. Behre, 1981; Giesecke et al., 2011; Sadori et al., 2013a), revealing valuable palaeoecological information that can assist with climate reconstructions (e.g. Bartlein et al., 2011; Mauri et al., 2015). Over the past 25 years there has been a growing body of knowledge relating to Holocene vegetation changes partic- 
ularly within the Mediterranean. This region is considered a hotspot of biodiversity (Médail and Quézel, 1999) as well as a climate change "hotspot" (Giorgi and Lionello, 2008). Recent research has highlighted possible anthropogenic influences along with the, often hard to separate, climatic signal through palaeoenvironmental reconstruction, such as to the west (Carrión et al., 2007; Estiarte et al., 2008; López Sáez et al., 2002; Pantaléon-Cano et al., 2003), centrally (Bellini et al., 2009; Calò et al., 2012; Combourieu Nebout et al., 2013; Di Rita and Magri, 2012; Noti et al., 2009; Peyron et al., 2011; Sadori et al., 2013b; Tinner et al., 2009), as well as in eastern areas (Bottema and Sarpaki, 2003; Finkelstein and Langgut, 2014; Hajar et al., 2010; Jahns, 2005; Kaniewski et al., 2014; van Zeist et al., 2009).

Numerous studies have highlighted the climatic contrast between the western versus eastern and northern versus southern sides of the Mediterranean Basin during the Holocene (Brayshaw et al., 2011; Jalut et al., 2009; Magny et al., 2012; Roberts et al., 2011, Peyron et al., 2013). It is generally considered that environmental change was primarily nature-dominated in the wetter early Holocene and humandominated in the warmer, drier late Holocene (Berger and Guilaine, 2009), with the mid-Holocene (6-3 ka BP) remaining a "melange" (Roberts et al., 2011); therefore focus is often placed on this mid-Holocene climatic transition (Collins et al., 2012; Fletcher et al., 2013; Mercuri et al., 2011; PérezObiol et al., 2011; Vannière et al., 2011).

Within the Mediterranean, the centrally located Maltese archipelago (Fig. 1a) provides a key site to study these dynamics in an island context during the Holocene. However, with no peat bogs or lake deposits, suitable sites for palaeovegetation data collection are very limited; notwithstanding this situation some recent research has been carried out on coastal areas (Carroll et al., 2012; Djamali et al., 2012; Fenech, 2007; Marriner et al., 2012).

The purpose of this study is to expand on the current knowledge of the Holocene vegetation dynamics on this strategically located archipelago, positioned almost midway between the western and eastern edges of the Mediterranean, through the study of a terrestrial core taken from Burmarrad, the second largest flood plain, on the Maltese Islands (Fig. 1d). This will allow for:

a. completing the previous results from Burmarrad obtained by Djamali et al. (2012), that covered a shorter period during the early to mid-Holocene (73505600 cal BP);

b. a new palaeovegetation reconstruction from 7280 to 1730 cal BP for NW Malta;

c. the first quantitative palaeoclimatic reconstruction for the Maltese islands.

It is hoped that the more interdisciplinary research conducted both within this archipelago and other Mediterranean locations will provide more data to enable concise reconstructions of the fluctuating vegetation assemblages and climatic variations present over the Holocene. This information, in turn, might provide a better understanding of the various processes and factors affecting not only past but also present and future landscapes.

\section{Setting}

\subsection{Location}

The Maltese archipelago (latitude: $35^{\circ} 48^{\prime} 28^{\prime \prime}-36^{\circ} 05^{\prime} 00^{\prime \prime} \mathrm{N}$, longitude: $14^{\circ} 11^{\prime} 04^{\prime \prime}-14^{\circ} 34^{\prime} 37^{\prime \prime} \mathrm{E}$ ) is approximately $96 \mathrm{~km}$ from Sicily and $290 \mathrm{~km}$ from the coast of Libya. The land area is nearly $316 \mathrm{~km}^{2}$, comprising of a number of small low-lying islands, three of which are inhabited - Fig. 1b; Malta $\left(245.7 \mathrm{~km}^{2}\right)$, Gozo $\left(67.1 \mathrm{~km}^{2}\right)$, and Comino $\left(2.8 \mathrm{~km}^{2}\right)$ - with a few uninhabited islets being less than $0.1 \mathrm{~km}^{2}$ in size (Cassar et al., 2008). The geology of the islands consists of five main types of sedimentary rocks: Upper Coralline Limestone, Greensand, Blue Clay, Globigerina Limestone, and Lower Coralline Limestone, deposited during the Oligocene and Miocene (Pedley et al., 2002). One of the most characteristic geomorphological features of the islands is the "wieden" (Chetcuti et al., 1992), a hybrid landform with a physical appearance of a river valley but in process more like an arid region's wadi (Anderson, 1997).

The archipelago's vegetation, similar to other Mediterranean islands and coastal areas, is strongly affected by intense summer heat and low precipitation, as well as increasing anthropogenic activity in recent millennia (Grove and Rackham, 2001; Roberts, 2014). Presently, the three main semi-natural vegetation types are garrigue, steppe, and maquis (Table 1), while there are a few much smaller communities developed as woodlands, in freshwater and on rocky habitats, on sand dunes and in coastal wetlands; these smaller communities are significant due to the rare endemic species found within them (Schembri, 1997).

Current evidence for the archipelago establishes human occupation on the islands at about 7200 years ago, with the initial settlers originating from Sicily (Blouet, 2007). During the period covered by the BM2 core the islands have undergone a succession of occupiers; during the Neolithic, Temple, and Bronze periods (Trump, 2002), as well as the Historical period with Phoenician, Punic, and Roman settlements (Bonanno, 2005).

\subsection{Climate}

The climate of the archipelago (Fig. 1c) is considered to be typically Mediterranean (Chetcuti et al., 1992), with mild, wet winters and hot, dry summers, while the spring and autumn seasons are short (Blondel et al., 2010). The annual precipitation is $530 \mathrm{~mm}$, with $70 \%$ of this rainfall occurring between October and March, though much is lost to evapotran- 


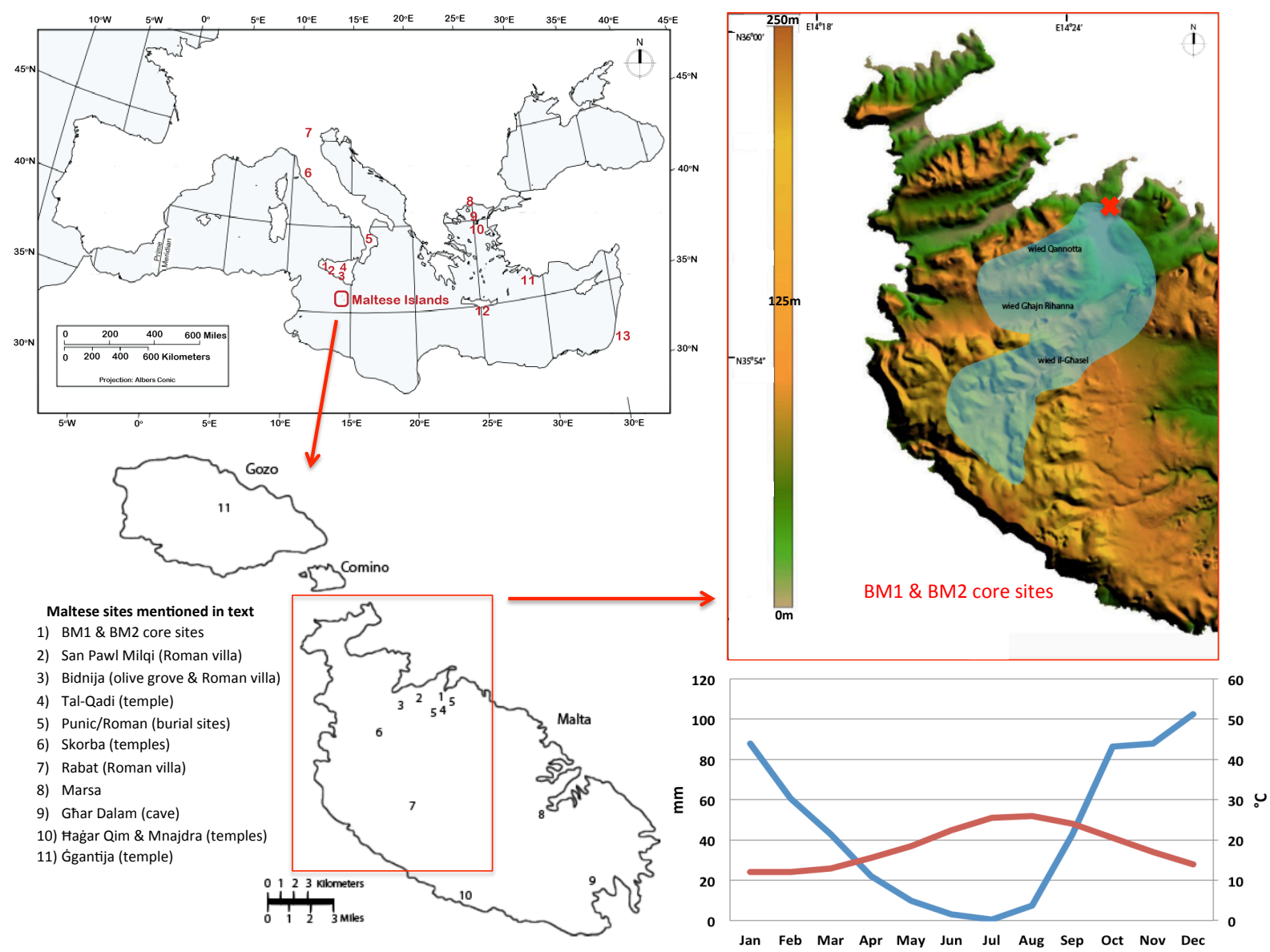

Figure 1. Study area. (a) Mediterranean region highlighting the Maltese Islands. Selected regional sites mentioned in text: 1: Lago Preola, 2: Gorgo Basso, 3: Biviere di Gela, 4: Lago Pergusa, 5: Lago Trifoglietti, 6: Lago Accesa, 7: Lago Ledro, 8: Tenaghi P., 9: SL152, 10: MNB-3, 11: NS14, 12: HCM2-22, 13: Soreq Cave; base map source: Arizona Geographic Alliance; (b) Maltese Islands: key sites mentioned in text; (c) average annual temperature and rainfall, based on Galdies (2011) data for the 30-year climatic period 1961-1990; (d) the topography and catchment area (blue) of Burmarrad.

Table 1. Selection of plant taxa characteristic of the main Maltese vegetation communities (adapted from Schembri, 1997; Stevens et al., 1995).

\begin{tabular}{ll}
\hline $\begin{array}{l}\text { Vegetation } \\
\text { community }\end{array}$ & selected main taxa \\
\hline Garrigue & Thymus capitatus, Erica multiflora, Euphorbia melitensis, Teucrium fruticans and Anthyllis hermanniae \\
Steppe & $\begin{array}{l}\text { Lygeum spartum (clay slopes) Hyparrhenia hirta, Andropogon distachyus and Brachypodium retusum. } \\
\text { Also Stipa capensis and Aegilops geniculata, Carlina involucrata, Notobasis syriaca, Galactites } \\
\text { tomentosa, Asphodelus aestivuus, and Urginea pancration }\end{array}$ \\
& Ceratonia siliqua, Olea europaea, Pistacia lentiscus, Rhamnus alaternus and Rhamnus oleoides \\
\hline
\end{tabular}


spiration (Anderson, 1997). The northwesterly wind (majjistral) is the most common wind direction for the islands, averaging about $20.7 \%$ of the days annually (Galdies, 2011).

\subsection{Burmarrad region}

The Burmarrad area where the BM2 core was taken (Fig. 1d) is currently an agricultural plain with a number of settlements, along with patches of maquis, garrigue, and steppe along its edges, as well as one small remnant stand of indigenous olive trees. Though hard to date, the latter are considered to be up to 1200 years old (Grech, 2001). Terracing with rubble walls for agricultural purposes can also be found on the rocky slopes of the catchment area. The present agricultural plain is subject to seasonal flooding; however, before silting in, there is strong archaeological evidence to suggest that it was used as a natural anchorage up until at least Roman times (Gambin, 2005; Trump, 1972). The earliest evidence for occupation in this area is in the form of a prehistoric tomb at San Pawl Milqi dating to 6050-5750 BP (Locatelli, 2001). The fluctuating cultural changes since this time have influenced the widespread landscape transformation during the Holocene not only in this area, but also throughout the archipelago.

\section{Methods}

Through the Franco-Maltese ANR project PaleoMed (C. Morhange, leader), a number of cores have been taken from locations on the Maltese archipelago with the aim of probing the islands' environmental history. A multidisciplinary team has been investigating a number of bodies of evidence including sediments, charcoal, pollen, and shells. A mid-Holocene section of the BM1 sediment core has been examined (Djamali et al., 2012); while geoarchaeological analysis of the Burmarrad area has been undertaken by Marriner et al. (2012).

\subsection{Coring and Sampling}

A percussion corer (diameter $10 \mathrm{~cm}$ ) was used to extract the BM2 core. The $10 \mathrm{~m}$ long core was sampled at regular 5$10 \mathrm{~cm}$ intervals, while the top $2 \mathrm{~m}$ was not considered due to proximity to the surface. The methodology used to define the sedimentary environments is based on high-resolution sedimentological and palaeoecological data (ostracods and marine molluscs); the initial facies descriptions (such as colour and lithofacies) were conducted under standardized laboratory conditions (see Marriner et al., 2012).

\subsection{Laboratory Analysis}

Pollen extraction was undertaken following the classic method described by Moore et al. (1991). Each of the $1 \mathrm{~cm}^{3}$ samples were chemically treated with $10 \% \mathrm{HCl}$ to remove the carbonate fraction, $48 \% \mathrm{HF}$ to remove the siliciclastic fraction, and concentrated $(37 \%) \mathrm{HCl}$ was used to remove the silicofluorides produced during HF treatment. Following these treatments, acetolysis was used to remove any organic material and to outline the pollen wall structure to aid identification. To calculate the pollen concentrations, a known amount of Lycopodium spore tablets were added to the samples prior to treatment. The pollen percentages are calculated using the pollen sum of all terrestrial pollen counted; it excludes Cyperaceae and other aquatic/hygrophilous species, NPPs (non-pollen palynomorphs), and undetermined/indeterminable grains.

A mean total count of at least 300 terrestrial pollen grains was used for each sample - this amount is considered sufficient to provide a fossil assemblage census (Benton and Harper, 2009). Pollen identification was undertaken using the IMBE's pollen reference collection and the pollen atlases of Europe and North Africa (Reille, 1992, 1995, 1998) along with the pollen atlas of Central Europe (Beug, 2004). Cerealtype pollen was described as Poaceae $>45 \mu \mathrm{m}$ with a minimum annulus diameter of 8-10 $\mu \mathrm{m}$ (following López-Merino et al., 2010).

NPPs were identified using a number of references: Cugny (2011), Mudie et al. (2011), Haas (1996), van Geel (1978), and Macphail and Stevenson (2004). Pollen percentages were calculated in TILIA, while pollen percentage diagrams were created using TGview (Grimm, 2004/5). Final diagrams were redrawn and amended in Adobe Illustrator. The pollen diagram taxa have been grouped according to ecology and life form: trees and shrubs, herbs, aquatic and hygrophilous species, coprophilous associated species, and NPPs. Microcharcoals (woody not herbaceous particles) smaller than $10 \mu \mathrm{m}$ were excluded from the count. The $L y$ copodium spore tablets and sample weight were also used to estimate microcharcoal concentrations (Stockmarr, 1971).

This paper presents the results of pollen analysis carried out on 48 samples collected from the BM2 core between the depths 210 and $1000 \mathrm{~cm}$. Some parts of the core did not provide any palynological material to be represented in the diagram (in particular the section between 450 and $240 \mathrm{~cm}$ ).

\subsection{Pollen-based quantitative climate reconstruction}

Use of only one method for pollen-based palaeoclimate reconstructions could reduce the robustness of the results obtained (Birks, 2011; Brewer et al., 2008), therefore a multimethod approach was utilized for the climatic reconstruction based on the BM2 data set. The chosen approach has been successfully used in studies throughout the Mediterranean area (Peyron et al., 2013; Sadori et al., 2013a). Three methods were chosen: the modern analogue technique "MAT" which compares past assemblages with modern assemblages (Guiot, 1990); the weighted averaging "WA" method (Ter Braak and Van Dam, 1989); and the weighted average-partial least square technique "WAPLS" (Ter Braak and Juggins, 
Table 2. Radiocarbon dates obtained from the Burmarrad BM2 core.

\begin{tabular}{lllll}
\hline Depth & Radiocarbon date & Calibrated age at $2 \sigma$ range & Laboratory reference & Material \\
\hline $500 \mathrm{~cm}$ & $3655 \pm 35 \mathrm{BP}$ & $3888-4086 \mathrm{cal} \mathrm{BP}$ & Poz-42682 & Wood Fragment \\
$705 \mathrm{~cm}$ & $3810 \pm 30 \mathrm{BP}$ & $4090-4347 \mathrm{cal} \mathrm{BP}$ & Poz-42443 & Grain \\
$820 \mathrm{~cm}$ & $4010 \pm 35 \mathrm{BP}$ & $4416-4568 \mathrm{cal} \mathrm{BP}$ & Poz-42442 & Charcoal \\
$980 \mathrm{~cm}$ & $6055 \pm 35 \mathrm{BP}$ & $6797-6995 \mathrm{cal} \mathrm{BP}$ & Poz-42444 & Charcoal \\
\hline
\end{tabular}

\section{BM2}

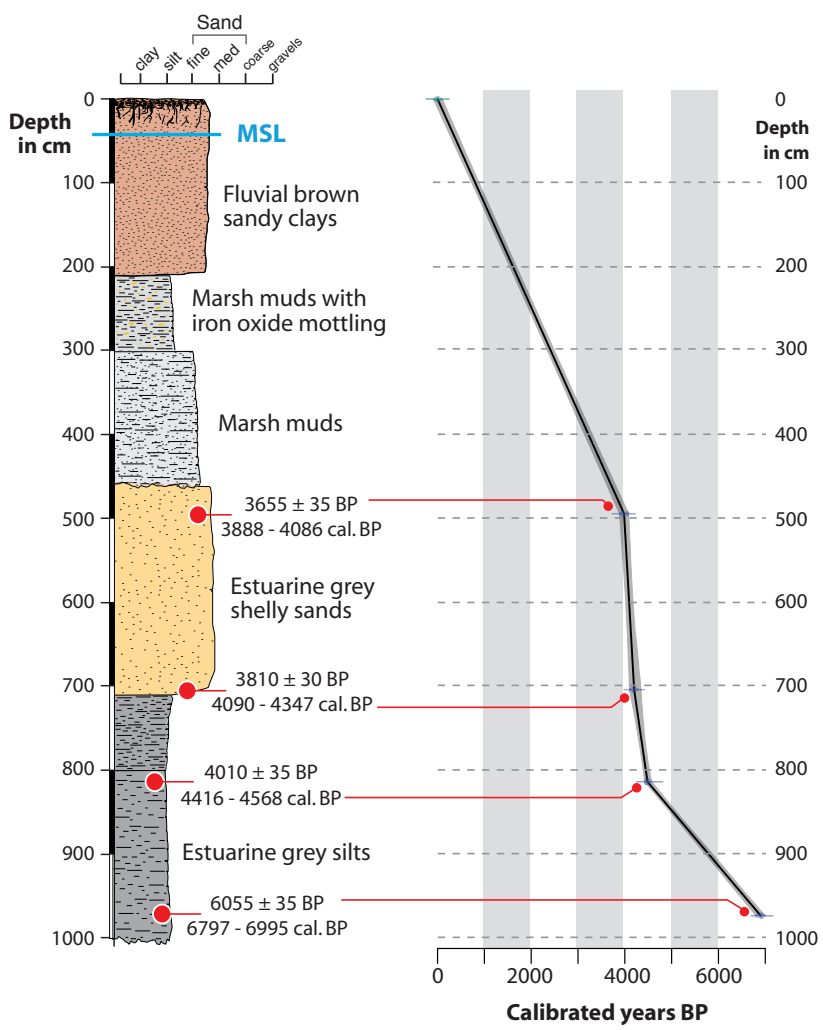

Figure 2. BM2 sedimentary profile and age-depth model interpolated curve.

1993). The MAT is the only one based on a comparison of past pollen assemblages to modern pollen assemblages, while the WA and WAPLS are transfer functions that require a statistical calibration between environmental variables and modern pollen assemblages; Peyron et al. (2013) provide a comprehensive outline of these three approaches. The climate parameters estimated from the Burmarrad core are the temperature of the coldest month (MTCO) and the seasonal precipitation. Calculations for the winter and summer precipitations are based on the sum of the months: December, January, February and June, July, August respectively.

\section{Results}

\subsection{Sediment and chronology}

The BM2 core has been subdivided into five lithostratigraphic zones (Fig. 2), recording a general transition from upper estuarine, through marine, to a marsh/fluvial environment. The visual core description is as follows: the lower part of the sequence is predominately composed of grey silts (Unit 1a: $1000-800 \mathrm{~cm}$ ) followed by slightly darker grey silts (Unit 1b: 800-710 cm) both deposited in an estuarine environment, grey shelly sands (Unit 2: 710-460 cm) deposited under marine conditions, marshy muds (Unit 3: 460-300 cm) and marshy muds with oxide mottling (Unit 4: 300-210 cm), and finally, at the upper part, brown sandy clays (Unit 5: 210$0 \mathrm{~cm}$ ). The two latter sedimentary units display different degrees of pedogenesis. No pollen samples were taken from the top $200 \mathrm{~cm}$ surface section due to the considerable biologic and anthropogenic activity that this layer is regarded to have undergone.

Four radiocarbon dates, calibrated using IntCal09 and Marine09 (Reimer et al., 2009) have been used for the BM2 core (Table 2). The samples used for the dating consisted of two charcoal pieces, one grain, and one wood fragment. An age model based on these four dates was constructed using the R-code Clam (Blaauw, 2010); this is obtained by repeated random sampling of the dates' calibrated distributions to produce a robust age-depth model through the sampled ages, displayed in the linear interpolation diagram (Fig. 2).

Results of the Accelerator Mass Spectrometry (AMS) dating are provided in Fig. 2. The lowest part of the core is radiocarbon dated to approximately $7280 \mathrm{cal}$ BP while the top corresponds to approximately $1730 \mathrm{cal} \mathrm{BP}$. The interpolated curve is quite steep in the midsection of this diagram. This may be an indication of anthropogenic activity in this area causing accelerated runoff and rapid infill of the plain during this period (Gambin, 2005; Marriner et al., 2012). Although all chronology should be treated with caution, it is noted that there is good correlation between the BM1 (Djamali et al., 2012) and BM2 cores. Reworking processes in low-energy ria environments such as these tends to be low; furthermore to overcome reservoir issues we have dated charcoal and short-lived plant material. Our interpretations are based on a chronological timescale established according to four radiocarbon dates; we assume that sedimentation rate in the intervals between the dating points remains relatively 


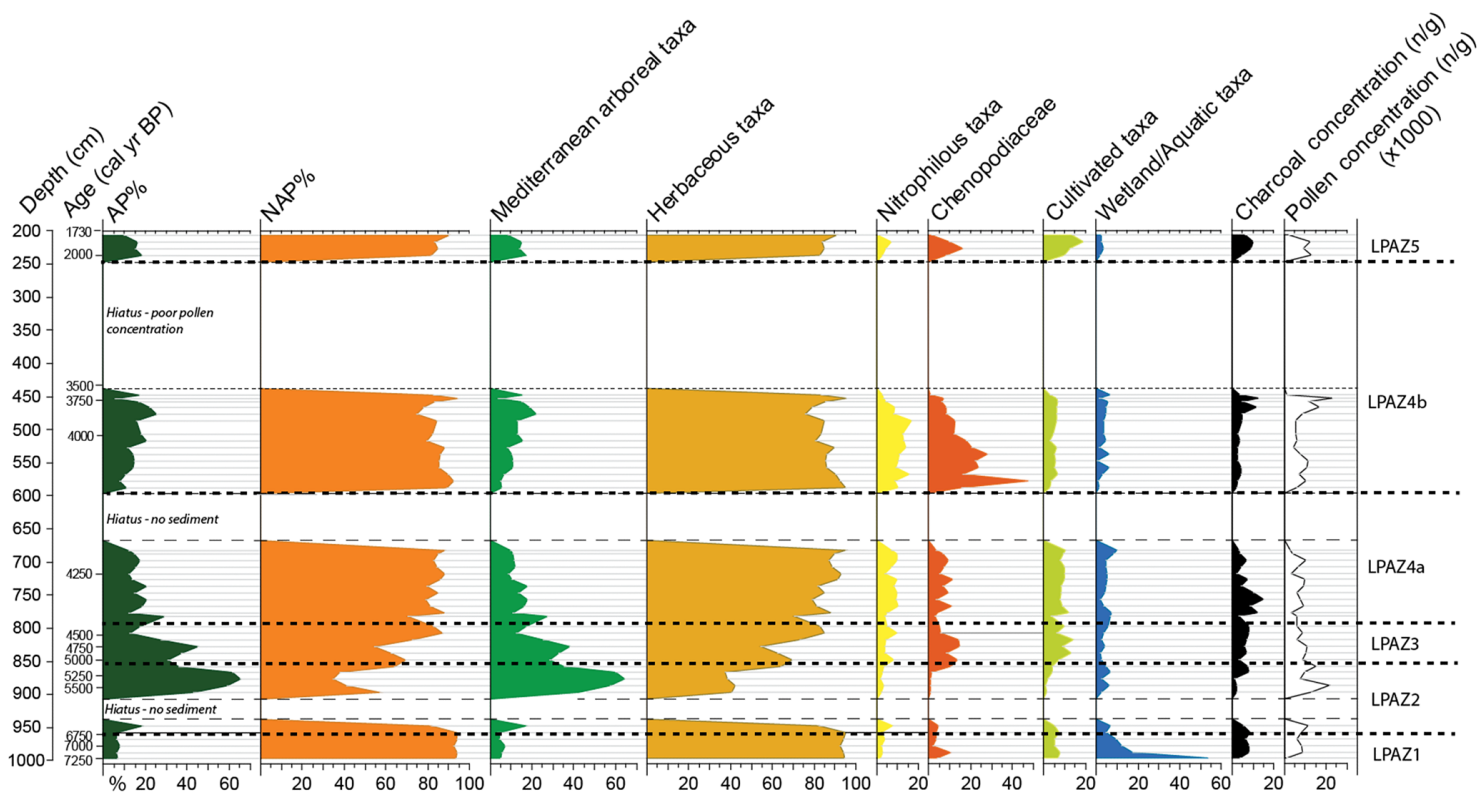

Figure 3. Burmarrad simplified pollen diagram: selected percentage curves and pollen concentration versus depth. Mediterranean arboreal taxa: Ephedra, Erica, Juniperus, Olea, Phillyrea, Pinus and Pistacia. Nitrophilous taxa: Rumex, Urtica and P. lanceolata-type. Cultivation indicator taxa: including crops (Cerealia-type, Triticum-type) and some associated secondary indicator species (Brassicaceae, Convolvulus). The pollen percentages are calculated using the pollen sum of all terrestrial pollen counted; it excludes Cyperaceae and other aquatic/hygrophilous species, NPPs (non-pollen palynomorphs), and undetermined/indeterminable grains. The microcharcoal concentration was calculated using the sample weight and number of Lycopodium spores observed (following Stockmarr, 1971).

constant; however, we do not exclude the possibility that in some depths, some changes in sedimentation rate may have occurred leading to slightly different ages for the observed environmental variations.

\subsection{Pollen diagram}

From the BM2 core only 48 of the 57 spectra are recorded in the pollen diagram due to poor pollen concentration (hiatus between depth 450 and $240 \mathrm{~cm}$ ). Two other smaller hiatuses appear in the record due to core recovery issues (940-890 and $680-600 \mathrm{~cm}$ ). The pollen concentration in the core generally was poor; however, the preservation of the grains was, on the whole, satisfactory. There was sufficient diversity of taxa to reflect pollen contributions from a number of habitats, including wetland as well as a variety of dry ground environments.

The pollen diagram provides percentages for all the terrestrial and aquatic pollen counted, as well as that of spores, microcharcoal, microforaminifera, and dinoflagellates; the pollen sum was calculated using terrestrial pollen totals only. No taxa were omitted from the pollen diagram. However, pollen productivity and dispersal levels (Hevly, 1981) and possible preservation variability (Havinga, 1971) have been considered (Figs. 3-6).

A total of 98 pollen and spore types were identified, including 17 arboreal pollen (AP) taxa and 56 non-arboreal pollen (NAP) taxa, the latter comprising herbs and weed species. With regard to NPP type, 17 different taxa were identified (Fig. 6). Following Cushing (1967) the diagram has been divided into Local Pollen Assemblage Zones (LPAZ) - these five zones are based on principle terrestrial taxa changes.

\subsubsection{LPAZ1 $(1000-960 \mathrm{~cm})$ Early Holocene: ca. $7280-6700$ cal BP}

The lower part of this zone $(980 \mathrm{~cm})$ is radiocarbon dated to $6055 \pm 35 \mathrm{BP}$. AP taxa are very low $(6$ and $8 \%)$ consisting of Quercus (deciduous and evergreen), Pistacia, and Erica arborea-type. NAP taxa are dominant, between 92 and $94 \%$, mostly composed of Cichorioideae, Poaceae, and Asteroideae, along with Chenopodiaceae, Convolvulus, Plantago, Cerealia-type. Microcharcoal was recorded at concentration levels start at 3.7, then fluctuate between 6.6 and 8.1. Microforaminifera range from 9.8 to $18.9 \%$, dinoflagellates, 50 to $14 \%$, and pollen of aquatic plants, at $3-6 \%$, the latter being at its highest percentage recorded throughout the five LPAZs. This zone dates to the early Neolithic, Ghar Dalam cultural phase. 


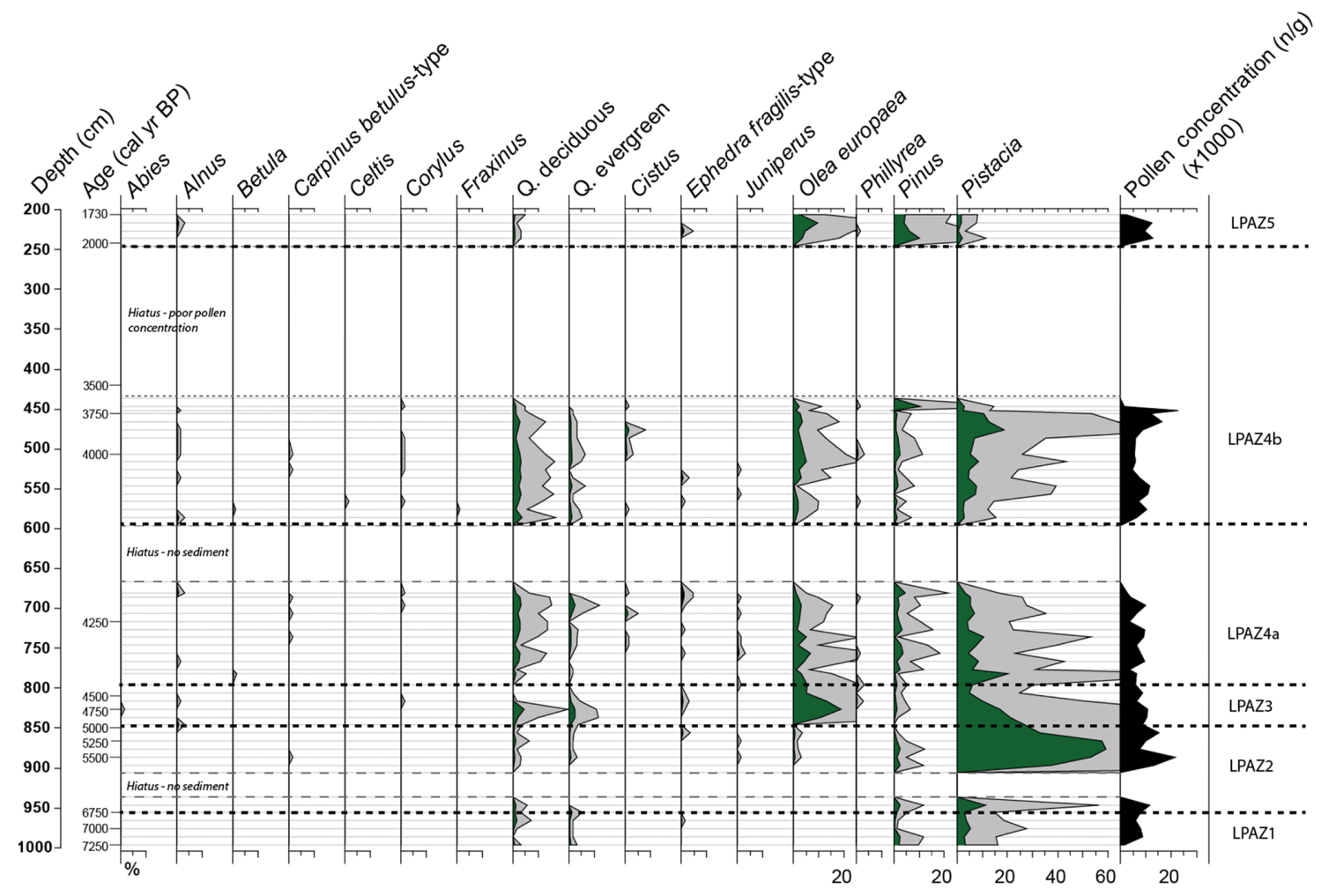

Figure 4. Burmarrad pollen percentage diagram versus depth: trees and shrubs. The pollen percentages are calculated using the pollen sum of all terrestrial pollen counted; it excludes Cyperaceae and other aquatic/hygrophilous species, NPPs, and undetermined/indeterminable grains.

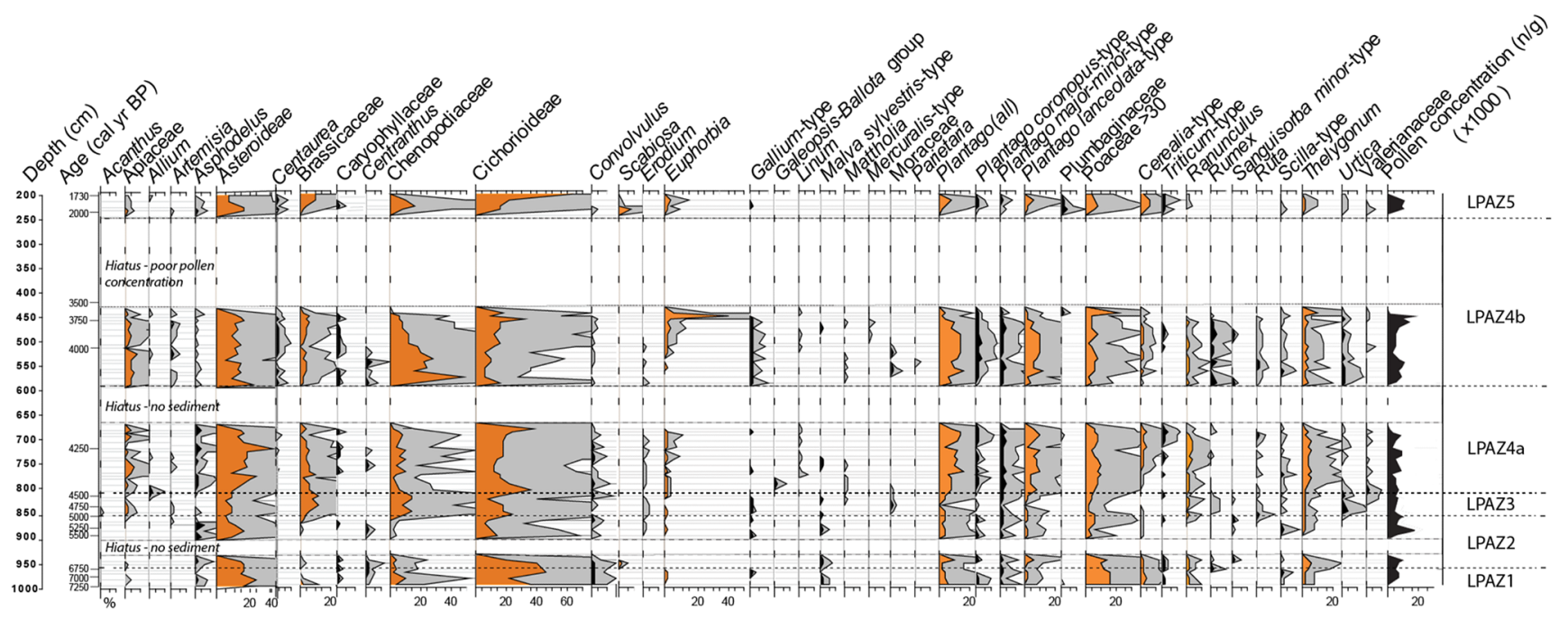

Figure 5. Burmarrad pollen percentage diagram versus depth: herbaceous taxa. The pollen percentages are calculated using the pollen sum of all terrestrial pollen counted; it excludes Cyperaceae and other aquatic/hygrophilous species, NPPs, and undetermined/indeterminable grains. 


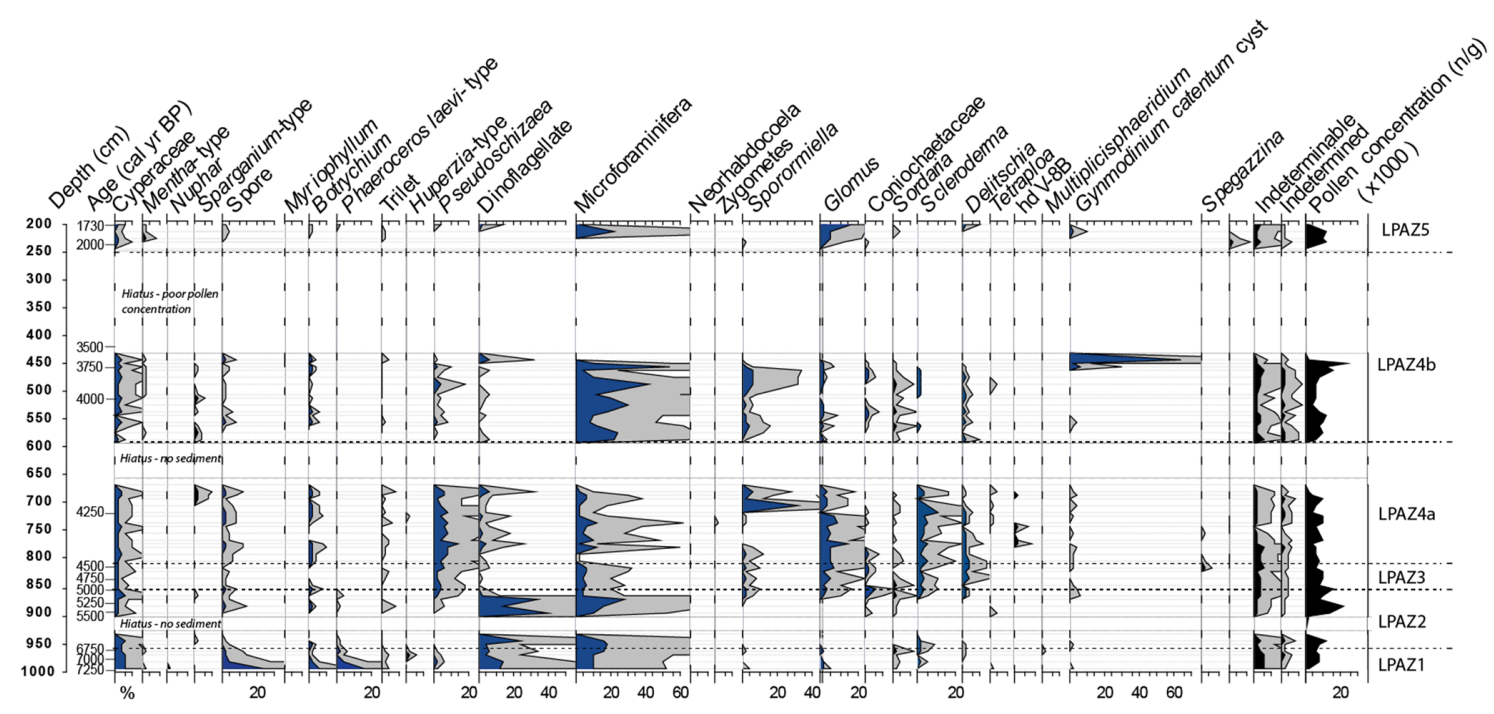

Figure 6. Burmarrad pollen percentage diagram versus depth: aquatic/wetland taxa and NPPs. The pollen percentages are calculated using the pollen sum of all terrestrial pollen counted; it excludes Cyperaceae and other aquatic/hygrophilous species, NPPs, and undetermined/indeterminable grains.

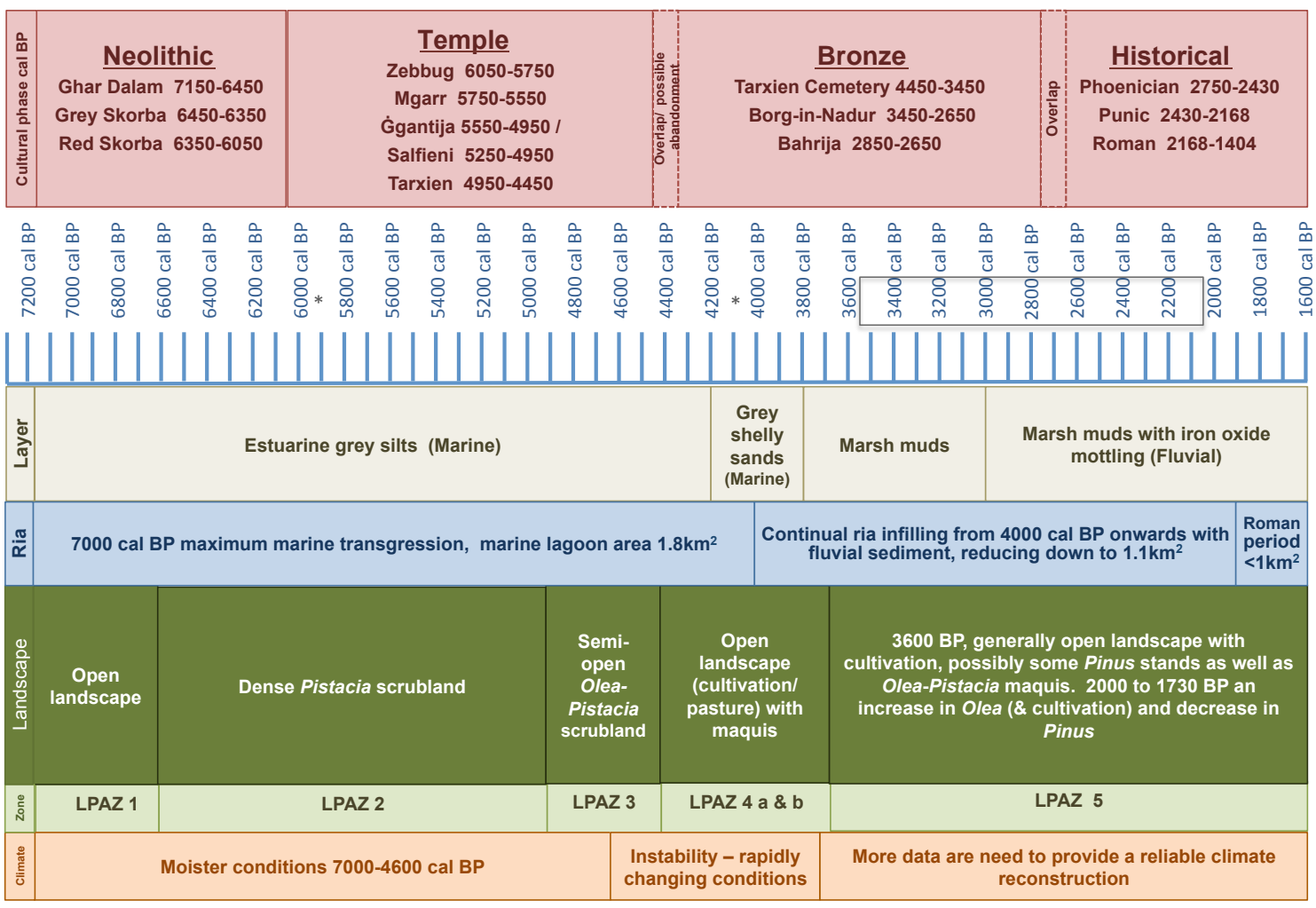

* short hiatus in records

Indicates gap in palynological records between 3600 to 2000 cal BP

Figure 7. Synthesis of cultural phases, LPAZs (local pollen assemblage zones), sediment, vegetation dynamics, and climatic reconstruction: BM2 core, Malta. 


\subsubsection{LPAZ2 $(960-850 \mathrm{~cm})$ Early to mid-Holocene: ca. $6700-5000$ cal BP}

This zone is characterized by a very significant rise in AP taxa, increasing to a maximum of $65 \%(880 \mathrm{~cm})$. The majority of this AP is comprised of Pistacia pollen (almost $60 \%$ ). NAP taxa are much lower than the previous zone, generally between 35 and $60 \%$. Cichorioideae, though beginning the zone at $21 \%$, dip to $7 \%$ before rising to $18 \%$. Poaceae significantly decrease to around $1 \%$. With regard to NPPs, though present in very low percentages in LPAZ1 there is also some presence of Glomus, Sporormiella, and Delitschia, while Coniochaeta appears for the first time, peaking at $5 \%$ $(860 \mathrm{~cm})$. Aquatics in this zone are slightly lower than in LPAZ1. Microcharcoal concentration decreases significantly after the transition to this zone ranging between 1.3 and 2.2 (the lowest level reached in the whole core sequence), then rising towards the end to 8.3, before decreasing slightly to 7.6. Dinoflagellates peak at the beginning of this zone at $40 \%$ diminishing to only $<1 \%$, while microforaminifera peak in the middle of this zone at $28 \%$ tapering off to $6 \%$. This zone covers both the Neolithic (end of Ghar Dalam, as well as Grey and Red Skorba) and Temple (Zebbug, Mgarr, Ġgantija and Salfieni) periods (Fig. 7).

\subsubsection{LPAZ3 $(850-800 \mathrm{~cm})$ Mid-Holocene: ca. $5000-4438$ cal BP}

This zone is radiocarbon dated to $4010 \pm 35 \mathrm{BP}$ at $820 \mathrm{~cm}$. AP vary between 13 and $45 \%$, while NAP taxa fluctuate between 55 and $87 \%$. The transition to this zone is marked by the significant rise in Olea, peaking at $19 \%(830 \mathrm{~cm})$. Pistacia, though relatively high at the beginning at $21 \%$, reaches a low of $6 \%(810 \mathrm{~cm})$. New AP taxa entering the record include Betula and Phillyrea, while deciduous Quercus records a highest peak of the whole core sequence in this zone at $4 \%$. Brassicaceae peak at $11 \%$ (its highest in the whole sequence) then decreases to $7 \%$. Pseudoschizaea has continued to increase from the previous zone, reaching $9 \%$ by the end of LPAZ3, while Glomus rises almost in unison to $7 \%$. Aquatics are at their lowest for the whole sequence. The microcharcoal concentration level is fairly high, ranging between 3.5 and $8.3 \%$. The comparable cultural phase (Fig. 7) is the end of the Temple period (Tarxien phase).

\subsubsection{LPAZ4a $(800-685 \mathrm{~cm})$ Mid- to Late Holocene: ca. $4438-4140$ cal BP}

The middle part of this sequence $(720 \mathrm{~cm})$ is radiocarbon dated to $3810 \pm 35 \mathrm{BP}$. AP are in decline, ranging between 12 and $29 \%$, while NAP are high, fluctuating between 71 and $88 \%$. Aquatic taxa remain fairly similar in percentage to LPAZ3. The beginning of this zone is marked by the highest microcharcoal concentration recorded, $14.9 \%$. Olea, though still present, has diminished drastically to values of $1-5 \%$ and Pistacia to between $<1$ and $10 \%$. Of the NAP, Apiaceae have increased up to $5 \%$, as have Asteroideae with a peak of $32 \%$ (the highest recorded in the core) and Plantago-type pollen, with $P$. lanceolata-type reaching its highest level in the core, $10 \%$. Sporormiella peak in this zone at $32 \%$, as do Pseudoschizaea at $14 \%$ and Glomus spp. at $15 \%$, the latter again mirroring the Pseudoschizaea increase. The cal BP dates correspond to the end of the Temple period (Tarxien) and beginning of the Bronze Age (Tarxien Cemetery).

\subsubsection{LPAZ4b $(685-455 \mathrm{~cm})$ Mid- to Late Holocene: ca. 4140-3682 cal BP}

The middle part of this sequence $(500 \mathrm{~cm})$ is radiocarbon dated to $3655 \pm 35 \mathrm{BP}$. AP are still relatively low, only ranging between 6 and $25 \%$, while NAP remain high: 75-95\% (highest recorded). Microcharcoal concentrations are generally much lower, ranging between 2.2 and 5.1 (except for two peaks at 12.7 and $11.6 \%$ towards the end). Olea, occurs between $<1$ and $4 \%$ and Pistacia only 3 to $19 \%$. Of the NAP taxa, Euphorbiaceae dramatically peaks at $41 \%$ and Apiaceae reach their peak with $7 \%$, while Asteroideae remain high with between 9 and $23 \%$, as does Cichorioideae, $32 \%$. Chenopodiaceae peaks at $48 \%$ (the highest in the whole sequence). Aquatic taxa are still low. Pseudoschizaea and Glomus spp. both remain relatively high. The zone corresponds to the beginning of the Bronze Age (Tarxien Cemetery phase).

\subsubsection{LPAZ5 $(455-210 \mathrm{~cm})$ the late Holocene: ca. 3682-1731 cal BP}

This last analysed section of the core has two notable AP species peaks, though as a whole sequence LPAZ5 records the lowest AP record of $10 \%$ dropping from $18 \%$, while NAP taxa remain high at $82-90 \%$. Firstly, the start of LPAZ5 has a significant Pinus increase - the pollen from this species has been present throughout all the zones at low levels, 0 $4 \%$, but now records a peak of $10 \%$. Pistacia on the other hand is present in its lowest percentages, between $<1$ and $4 \%$. Towards the end of this zone a second but smaller Olea peak occurs, reaching $10 \%$, while NAP taxa Cerealiatype pollen (Triticum, $2 \%$ ), $7 \%$, Cichorioideae, $63 \%$, Brassicaceae, $11 \%$, and Scabiosa, $7 \%$, all record peaks. Aquatic taxa are recorded at their lowest levels. This last zone also has another two microcharcoal concentration peaks reaching 9.2 and 10.4. This final LPAZ starts within the Bronze Age (Tarxien Cemetery) phase, followed by a break in the palynological record (3600-2000 cal BP), and ends within the early Roman phase.

\subsection{Climate reconstruction for the Burmarrad area, Malta}

A quantitative climate reconstruction has been performed for Malta on the BM2 pollen sequence. The results (Fig. 8) 
include: temperature, MTCO (mean temperature coldest month), and winter and summer precipitation. The findings are compared and contrasted with other Mediterranean climate reconstructions (see Sect. 5.2).

\subsubsection{Temperature reconstruction - MTCO}

Between ca. 7000 and $4800 \mathrm{cal} \mathrm{BP}$ the temperature (MTCO) is fairly stable at around $11^{\circ} \mathrm{C}$, close to present-day values. After 4800 the temperature becomes more unstable with a minimum at $7^{\circ} \mathrm{C}(\sim 4100 \mathrm{cal} \mathrm{BP})$ and maximum at $14^{\circ} \mathrm{C}$ ( $3700 \mathrm{cal} \mathrm{BP}$ ). Just after this period there is a sharp decline. However, more data would be necessary to confirm this trend. After $3600 \mathrm{calBP}$ the dashed line is due to an absence of palynological data for this period. The period between 2000 and $1800 \mathrm{cal} \mathrm{BP}$ is marked by a brief increase in temperature to $12^{\circ} \mathrm{C}$ close to the present-day coldest month mean minimum temperature for Malta.

\subsubsection{Precipitation reconstruction}

Winter precipitation displays much more variability than summer. Although reconstructed values differ following different methods (MAT, WAPLS, and WA) they illustrate the same trends. From 7000 to 4600 cal BP both winter and summer precipitation are generally high and tend to decrease especially after $6000 \mathrm{cal}$ BP. The period between 4500 and 3800 cal BP is characterized by low winter precipitation indicating a dry period. Again there is no fluctuation displayed between 3700 and $2000 \mathrm{cal} \mathrm{BP}$ due to a break in the sequence. Between 2000 and 1800 cal BP precipitation values are under the present-day ones.

\section{Discussion}

\subsection{Vegetation dynamics and climate fluctuations}

A number of studies have highlighted the problem of disentangling the human- and climate-induced changes in the Mediterranean region (e.g. Behre, 1990; Pons and Quezel, 1985; Sadori et al., 2004; Roberts et al., 2011; Zanchetta et al., 2013). More often than not it may be a fluctuating combination of these two forces driving the changes rather than a single factor, with one amplifying or even moderating the vegetation signals provided in the palynological record. While it is acknowledged that vegetation patterns can vary even within small island settings such as Malta (Hunt, 2015), the BM2 core provides insight into both changing vegetation dynamics and hydroclimatic fluctuations in the Burmarrad valley system from 7280 to $1730 \mathrm{cal} \mathrm{BP}$.

\subsubsection{Early Neolithic}

Trump (2002) states that evidence of the first settlers in Malta, around 7200-7000 BP, is found at the Skorba and

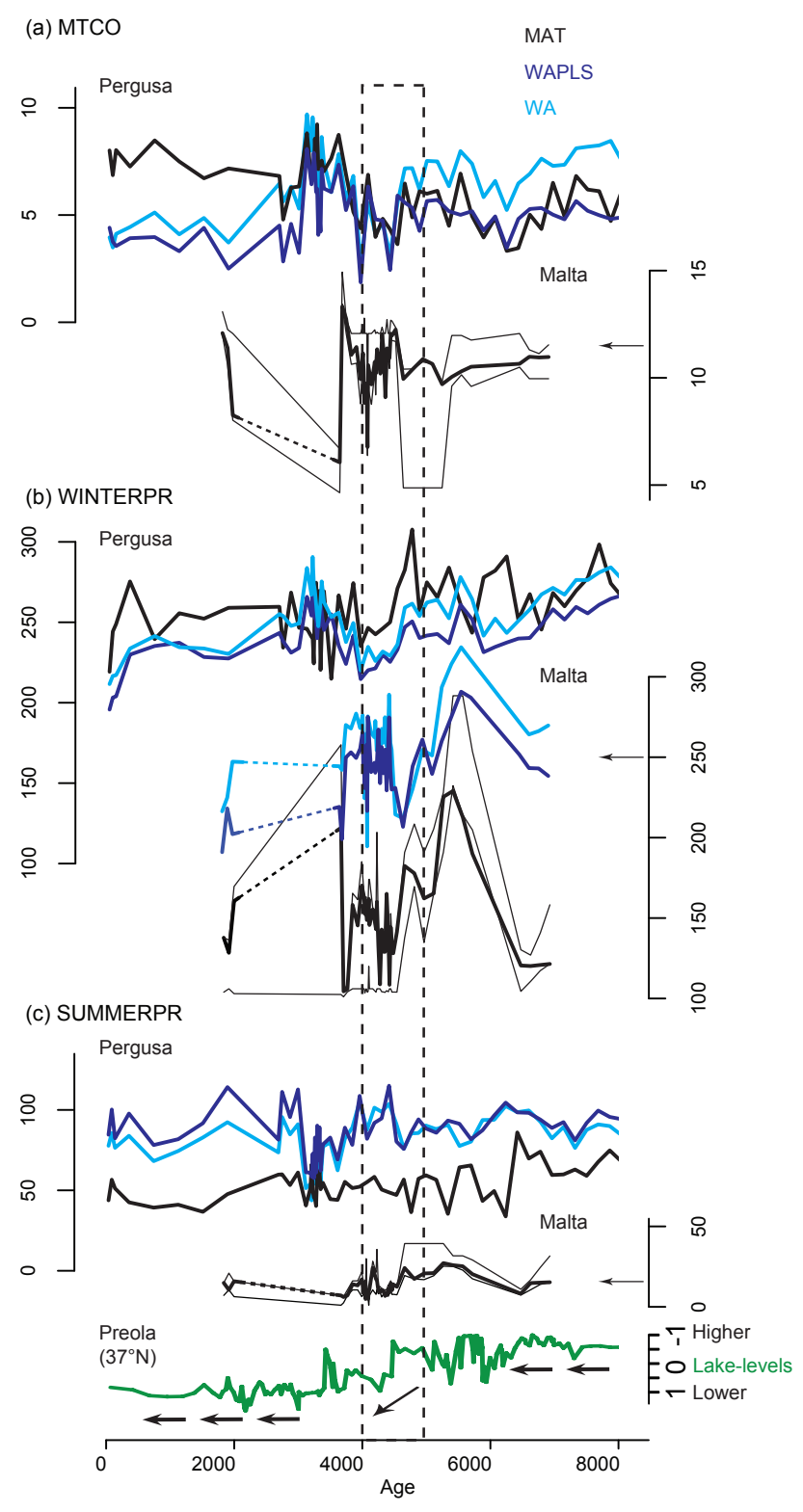

Figure 8. Comparison between pollen-inferred climate for Malta $\left(35.9^{\circ} \mathrm{N}\right.$, Burmarrad, Malta) and Lago Pergusa ( $37.5^{\circ} \mathrm{N}$, Sicily) using MAT (modern analogue technique), WAPLS (weighted averagepartial least-squares technique), and WA (weighted averaging) and lake levels for Lago Preola (37.4 ${ }^{\circ} \mathrm{N}$, Sicily). (a) Mean temperature of coldest month (MTCO), (b) winter precipitation (WINTERPR), (c) summer precipitation (SUMMERPR). (Malta's present-day values are indicated with an arrow on the scale bar).

Ghar Dalam prehistoric sites. These original occupiers coming from Sicily (Blouet, 2007), brought with them knowledge in tool making (stone, wood, and bone) and agricultural practices (Pace, 2004), as well as crop (barley, lentils, emmer, and club wheat) and domesticated animals such as sheep, goats, cattle, and pigs (Trump, 1972). However, the exact date when humans arrived in Malta remains a key ques- 
tion. Broodbank (2013) postulates that permanent Mediterranean island settlements were probably preceded by early visitations. However, these remain "archaeologically invisible" (Colledge and Conolly, 2007). The Mediterranean Sea, as well as other areas such as the Persian Gulf (Wells, 1922), were being sailed as early as $9950 \mathrm{cal}$ BP. Even before the Holocene epoch, during the Upper Palaeolithic and Younger Dryas, coastal and island crossings were taking place (Broodbank, 2006, 2013); given the inter-island visibility and this early movement of seafarers, it is plausible that the Maltese islands may have been visited, and possibly temporarily occupied, before being permanently settled during the Neolithic.

Much of southern mainland Europe saw decreasing deciduous woodland areas (from the early Neolithic onwards, Delhon et al., 2009). This vegetation does not appear abundant on the Maltese Islands during this period (Carroll et al., 2012; Djamali et al., 2012), though it has been postulated that deciduous forest was the dominant vegetation at this time (Grech, 2001). Evidence for the environment during this early Neolithic period in Burmarrad suggests an initially open landscape at ca. 7280-6700 cal BP surrounding a large palaeobay during the maximum marine transgression period (Marriner et al., 2012) with mainly non-arboreal pollen and aquatic/wetland taxa. Recorded species indicating this environment are Botryococcus, a common green algae and Phaeroceros laevis, a bryophyte, which is associated with continually moist or slightly wet, often acidic, soils (Boros et al., 1993), generally located in flood plains, ditches, streams, and freshwater marsh areas. It is also considered one of the initial species post-fire events (Bates, 2009). However, P. laevis, similar to most bryophytes, is not associated with halophytic conditions (Warny et al., 2012). This species might also be considered an indicator of human activity (Djamali et al., 2012). These results are consistent with pollen records from the BM1 core, dated to a similar period from the same flood plain (Djamali et al., 2012), as well as the coastal areas of the neighbouring island of Sicily (Noti et al., 2009) and SE Spain just prior to 7000 cal BP (Pantaléon-Cano et al., 2003). However, not all Mediterranean coastal sites had an open environment at this time, with some areas experiencing it earlier, such as other coastal and inland regions in Sicily (Calò et al., 2012; Tinner et al., 2009) and western Greece (Avramidis et al., 2012).

Although the evidence from the BM2 core and the BM1 core (Djamali et al., 2012) points to this area having an open landscape, it is necessary to highlight that there are Maltese archaeological records from the Neolithic period from other locations. Such evidence might point to a different more "woody" environment, such as the discovery of Cercis siliquastrum, Crataegus sp., and Fraxinus sp. charcoal remains (Metcalfe, 1966). Both C. siliquestrum (Fabaceae) and Crataegus (Rosaceae) are extremely under-represented in pollen diagrams, due to the low pollen production and their dispersal methods. These are deciduous arboreal taxa that ei- ther did not appear in the pollen record of the BM2 core or only in minimal and infrequent quantities. Therefore, these species may have originated in isolated patches in other regions on the archipelago or were brought as timber to the island by the early farmers or trading seafarers along with other goods.

Many of the key anthropogenic pollen indicators (API) used in different parts of the Mediterranean region, such as primary crop species (Vitis, Olea, cereals, and pulses) and secondary "weed" species (Artemisia, Chenopodiaceae, $P$. lanceolata, Rumex, Urtica), are native to the Mediterranean area (Brun et al., 2007; Grove and Rackham, 2001; Mercuri et al., 2013a; Sadori et al., 2013a) making it difficult to state with any certainty that an individual species is evidence of anthropogenic activity - although it may be possible to take a combination of key cultivated and ruderal species to provide a stronger indication of human presence (such as Carrión et al., 2010a; Behre, 1990), even if this activity only has a weak influence on the natural vegetation or perhaps acts as an amplifier to the stronger climatic stimulus. Using the works of Andrieu-Ponel et al. (1999), Behre (1990), Brun et al. (2007), Carrión et al. (2010a), Li et al. (2008), and Mercuri et al. (2013a, b), selected taxa from the BM2 core have been identified with consideration of their biogeography to highlight potential evidence of human activity throughout the sequence: cultivated (which includes cereals and associated secondary indicator taxa) and nitrophilous species (taxa often inferring livestock, pasture, and settlement) (Fig. 3). Based on different groups of API, we suggest that traces of human activity are present from the base of the BM2 core (7280 cal BP), similar to Noti et al.'s (2009) southern Sicily results - crop taxa (Cerealia-type) and associated ruderal species (such as $P$. lanceolata, Chenopodiaceae, $\mathrm{Ci}$ chorioideae, Brassicaceae, and Sporormiella) are noted from the start of the early Neolithic onwards.

These initial traces of palynological evidence, mainly based on NAP taxa which are, due to their phenology, considered more sensitive and responsive to environmental change (Markgraf and Kenny, 2013), coincide with archeological evidence for nearby permanent dwelling structures on the island (Pace, 2004; Trump, 2002), as well as abundant microcharcoals - the latter might be indicative of landscape modification through the use of fire, which has been recorded during the same time period in neighbouring Sicily (Noti et al., 2009) as well as throughout other Mediterranean areas (Vannière et al., 2011), although climate-driven fire events cannot be discounted (Sadori et al., 2015a). Nonetheless, the extent to which these first recorded settlers actually impacted the landscape from its "original state" is hard to decipher without pre-occupation data. What is clear is that arboreal pollen was extremely low in this catchment area during the early Neolithic, and those tree species actually recorded in the pollen sequence, such as Pinus, may well have been present due to long-distance transportation (Calò et al., 2012; Court-Picon et al., 2006; Hjelle, 1999). 


\subsubsection{Mid Neolithic to early Temple Period}

The three cultural phases of the Maltese Neolithic period are delineated mainly by changes in pottery styles, the initial style being almost identical to pottery found in Stentinello, Sicily (Trump, 2004). These remains have been recovered from both the Ghar Dalam cave and the Skorba huts, the latter located very close to the Burmarrad catchment area (Fig. 1b), as well as fragments for other locations in the archipelago including Gozo. It is highly probable that during this first Ghar Dalam phase (Fig. 7) many more geographically important sites around the island were being settled (Pace, 2004), while farming customs and practices were possibly undergoing adaptation. The first temples were built later - ca. 5450 cal BP during the Ġgantija phase (Fig. 7).

The major recorded change in the landscape is from a predominantly open herbaceous and wetland environment, to a much more closed evergreen arboreal cover. At ca. 6700 cal BP there is a rapid expansion of Pistacia, reaching a peak of $60 \%$ at $5500 \mathrm{cal} \mathrm{BP}$ - this peak coincides with the boundary between the Zebbug and Mgarr phases of the Temple Period (Fig. 7). Evidence from these phases can be found within the catchment area, such as the tomb dating to the Zebbug phase at San Pawl Milqi. These unusually high percentages for Pistacia, generally considered underrepresented in records (Collins et al., 2012), produce low to moderate pollen quantities that are poorly dispersed (Beer et al., 2007), suggestive of very dense areas of Pistacia scrubland within the Burmarrad catchment area. This high percentage was also recorded by Djamali et al. (2012) in the same plain (BM1 core). However, it was not part of the pollen records from Carroll et al. (2012) taken from Salina Bay, situated within the same catchment area as the BM1 and BM2 cores. This may be due to a number of reasons: Pistacia pollen not dispersing to the Salina core site (for example, geomorphic, hydrologic and/or vegetative features in the landscape affecting pollen movement), different preservation or deposition conditions within the core sediments, and/or different methods utilized for the pollen extraction process.

Similar rapid and large expansion of Pistacia during this period appears in records from Sicily at Biviere de Gela (Noti et al., 2009), Lago Preola (Calò et al., 2012), and Gorgo Basso, where an earlier even larger expansion is recorded between 10000 and $7500 \mathrm{yr}$ cal BP (Tinner et al., 2009). This earlier Pistacia peak and subsequent decline were also noted in Crete (Bottema and Sarpaki, 2003) and western Greece (Jahns, 2003). Djamali et al. (2012) provide a concise account of the life cycle, distribution, and possible expansion time frame difference of this genus in relation to the Malta record. The trigger for this Pistacia increase has been proposed as being climatic in origin. Noti et al. (2007) suggest that the expansion of forests and scrublands between 7000 and $5000 \mathrm{cal}$ BP recorded in southern Sicily is due to increased moisture availability at this time, which is also noted in southern Spain (Carrión, 2002).
With regard to NAP taxa, the level recorded is the lowest within the whole sequence, with particularly low percentages of nitrophilous taxa, supporting the theory of dense scrubland, that would restrict the growth of other plant species. Chenopodiaceae taxa use, as a possible indictor of a nitrophilous environment, is treated with caution. Many in this taxon are known halophytes (Grigore et al., 2008) and possess a close association with aridity (Pyankov et al., 2000); therefore their use, especially given this coastal zone context, is always in conjunction with other key taxa. Additionally, there is the lowest level of Poaceae, including Cerealia-type (Triticum-type), further confirming the dense scrubland scenario. Microcharcoal quantities are also at their lowest levels, a decrease that is noted in other sites in southern European localities, such as Lago Pergusa (Sadori and Giardini, 2007) and Trifoglietti (Joannin et al., 2012) in Italy. Sadori and Giardini (2007) state that this decline in fire events corresponds to forest closing; in the case of Burmarrad this could be considered as scrubland closing.

Burmarrad's palaeo-lagoon is still present during this period, with key indicator species such as dinoflagellates reaching their highest level; these are primarily marine organisms (Traverse, 2008). Their presence confirms the lower estuarine environment at the site recorded in both BM1 (Djamali et al., 2012; Marriner et al., 2012) and BM2 (this study).

\subsubsection{Late Temple Period}

The Temple period in Malta lasted between 6050 and $4450 \mathrm{cal} \mathrm{BP}$; this period is unique to the archipelago (Pace, 2004). To date, nowhere else in the world are there freestanding stone buildings (such as Hagar Qim, Mnajdra, and Ggantija, Fig. 1b) dating to this period. The first temple structure is dated to ca. 5450 cal BP, built during the Ggantija phase (Fig. 7). The purpose of these buildings is thought to be for ritual purposes, for the estimated 10000 people settled on the islands at this time (Trump, 2002).

During this temple-building phase there is a notable increase of Olea from $4938 \mathrm{cal} \mathrm{BP}$ peaking at $4635 \mathrm{cal} \mathrm{BP}$ $(20 \%)$. This increase in Olea is similar to that observed in Sicily and Minorca around 5000 cal BP (Pérez-Obiol and Sadori, 2007). However, this increase is later than that noted by Tinner et al. (2009) at Gorgo Basso (6500 cal BP), but earlier than the one recorded by Sadori et al. (2013) at Pergusa ( $3200 \mathrm{cal} \mathrm{BP}$ ), an increase that they propose is less likely to be "natural" in origin. Pérez-Obiol and Sadori (2007) argue that it is difficult to state whether these early increases in Olea are climatic or anthropogenic in origin; though likely driven by climate, the possibility that Neolithic people were cultivating it cannot be excluded (Beaulieu et al., 2005). Carrión et al. (2010b) through wood-charcoal and wood analysis from prehistoric sites have shown that Olea europaea L. var. sylvestris, the oleaster (shrubby form), was abundant in the western Mediterranean during the early to mid-Holocene (8800-5600 cal BP), and they suggest that it may have been 
the dominant species in thermophilous plant formations during this time, with wild varieties thriving in the warmest regions and generally near coastal areas. The oleaster usually takes a shrubby form while the Olea europaea L. var. europaea is more tree-like. Davis (1994) suggests that Olea levels around $20 \%$ might be indicative of local cultivation (within $5 \mathrm{~km}$ ) while values $>5 \%$ may indicate olive cultivation on a wider regional scale.

With this increase in Olea there is also a steady increase in herbaceous taxa, particularly nitrophilous and anthropogenic pollen indicator species (Fig. 3). Another significant increase is seen in Brassicaceae - though previously at minimal levels, it now reaches around $15 \%$. Noti et al. (2009) also observed an increase in herbaceous taxa at Biviere di Gela in southern Sicily (namely Chenopodiaceae-type, Cichorioideae, Brassicaceae, Mercurialis annua, and Rumex acetosella-type) at around the same time. The issue with Brassicaceae (along with Asteraceae, Chenopodiaceae, Poaceae, and Rubiaceae) is the fact that it has undifferentiated families composing arable weeds, as well as disturbed habitats and sometimes marsh-plant species such as Nasturtium officinale (Zeist et al., 2009) and the pollen produced only shows slight morphological variation, so taxonomic level determination generally only reaches genus or family level (Brun et al., 2007). Therefore an increase in Brassicaceae by itself might not be a clear indicator of human activity. However, when combined with the increase in other taxa such as Plantagotype, Poaceae, Cerealia-type, and/or Rumex (Costantini et al., 2009; Djamali et al., 2012) or Sordariaceae (Carrión et al., 2007), this can strengthen its signal of anthropogenic presence, in the latter case suggesting possible pastoral activity. In this regard, in the BM2 core, there is a synchronous increase in API taxa (e.g. Chenopodiaceae, Plantago-type, Poaceae, and Rumex) with Brassicaceae, as well as an increase in coprophilous-associated NPPs such as Sordaria, Delitschia, Coniochaetaceae, and Sporormiella (Cugny et al., 2010; Gelorini et al., 2012), suggestive of human activity, particularly the possible grazing of livestock in the area.

\subsubsection{Bronze Age}

The Bronze Age in Malta occurred between 4450 and 2650 cal BP (Fig. 7), and is divided into three phases representing different colonizations of these islands: Tarxien Cemetery, Borg-In-Nadur, and Bahrija, the latter settlers co-inhabiting the island with the Borg-In-Nadur people for about 200 years (Pace, 2004). Trump (2004) suggests that the difference in cultures between the Temple and Bronze Age is so apparent that it is possible that the islands passed through a phase of abandonment, though this remains the subject of an ongoing debate. During the Bronze Age, fortified settlements were built on strategically located hilltops complete with underground food storage facilities known as "silo-piths" (Buhagiar, 2007), while dolmen structures (possibly used for the burial of cremated remains) were also con- structed. Even though there is evidence that these Bronze Age people built dwellings and undertook agricultural activity, including livestock management and possible crop rotation (Fenech, 2007), the previous Temple Period, with its megalithic temple civilization, is considered culturally and economically superior (Buhagiar, 2014). The population of the islands during the Bronze Age is suggested to have been smaller than that of the Temple period (Blouet, 2007), though their impact on the landscape can still be traced. One such impact found around the islands is the ancient cart rut tracks. These parallel channels are incised into the limestone rock (Hughes, 1999) - 22 such networks have been recorded in the Burmarrad catchment area alone (Trump, 2004). There has been speculation on the origin, use, and date of these cart ruts since they were first referenced in 1647 by Gian Francesco Abela, one of Malta's earliest historians (Hughes, 1999; Mottershead et al., 2008). Although it is not this paper's purpose to delve into their much-debated chronology and use, it is pertinent to point out that at least some are suggested to be Bronze Age in origin (Trump, 2004).

Throughout the early and mid-Bronze Age, arboreal species in the Burmarrad catchment area are decreasing in abundance, while herbaceous taxa are increasing, suggesting the opening up of the landscape. Furthermore, the increased microcharcoal concentration at the start of this sequence might indicate the use of slash-and-burn to this end. This increase in fire activity around $4500 \mathrm{cal} \mathrm{BP}$ is also noted in southern Sicily at Gela di Biviere (Noti et al., 2009) and slightly earlier (5000 cal BP) at Lago Pergusa (Sadori and Giardini, 2007). It is also observed as a general trend in the Mediterranean from around 4000-3000 cal. BP (Vannière et al., 2011). The cause of this increased fire activity is suggested to be partly due to human activity and associated disturbances.

Pastoral activity plant indicators (such as Rumex and Plantago lanceolata-type) reach their highest levels in this sequence. P. lanceolata is known to grow in both hay meadows and grazed areas (Briggs, 2009), though there are distinct ecotypic variants for co-adaptive traits depending on the habitat (Van Groenendael, 1986; Steans, 1976, cited in Briggs, 2009). However, further evidence including a very significant increase in Sporomiella, a coprophilious fungi associated with pastoral activities (Pavlopoulos et al., 2010), along with increases in nitrophilous taxa (Li et al., 2008) such as Urtica and an exceptionally large peak in Chenopodiaceae, at ca. 4000 cal BP, strengthens the interpretation that land use in the Burmarrad area included grazing from around 4200 cal BP onwards. This increase in the use of livestock supports the argument put forward by Blouet (2007) whereby he proposes that, during the Bronze Age, "war-like" conditions led to a shift towards livestock use rather than crop cultivation, due to the ability to be able to move animals quickly into the fortified settlements.

The early part of the Bronze Age in this area is also marked by a rise in Pseudoschizaea (a Zygnematacean algae spore) 
and Glomus (Glomaceae). Carrión et al. (2010) state that an increase in both these taxa may indicate increased soil erosion. Supporting this idea, increasing Glomus spp were noted by Ejarque et al. (2011) in areas of greater soil perturbance and erosion. Furthermore, Estiarte et al. (2008) describe Pseudoschizaea as indicative of soil erosive activity, especially when associated with certain taxa, such as Asteraceae, that are known markers of edaphic processes. In the case of the early Bronze Age in Burmarrad, there is an increase in Asteraceae coinciding with the increase of Glomus spp and Pseudoschizaea, further supporting the suggestion that during this time there is increased erosional activity, which is synchronous with a reduction in pollen concentration rate as well as reduced arboreal taxa. This increased erosion can also be seen within the changing dynamics of the ria. At around $7000 \mathrm{cal} \mathrm{BP}$ the area formed a marine lagoon (area ca. $1.8 \mathrm{~km}^{2}$ ), followed by a sharp decrease in marine mollusc taxa from ca. $4000 \mathrm{cal} \mathrm{BP}$, with the area infilling with fluvial sediment and gradually becoming landlocked (Marriner et al., 2012).

This increasing human pressure on the landscape during the Bronze Age is not isolated to the Maltese archipelago or the central Mediterranean area (Mercuri, 2014) it has also been recorded throughout the whole region, between 5000 and $3000 \mathrm{cal} \mathrm{BP}$, as societies and their associated ecological disturbances become more apparent (Sadori and Giardini, 2007; Mercuri et al., 2015). Sadori et al. (2011) note two signals within the Mediterranean; the first corresponds to a climate event of 4300-3800 BP (Magny et al., 2009), that of a sudden and brief episode between 4400 and $4100 \mathrm{cal} \mathrm{BP}$ which initially affects the arboreal pollen concentration followed by the percentages (generally being accompanied by human presence indicators), then a second between 3900 and $3400 \mathrm{BP}$, which they suggest is slightly longer and involved intensive land exploitation.

Towards the latter part of this period in Burmarrad (ca. $3600 \mathrm{cal} \mathrm{BP}$ ) the remaining Mediterranean arboreal taxa decline again. However, there is a distinct increase in Pinus, reaching over $10 \%$ from its previous levels of $1-4 \%$ throughout the whole sequence. MacDonald and Cwynar (1985) suggest that when Pinus reaches $20 \%$ it becomes significant in the environment, lower percentages being more likely due to background noise from long-distant transport. Furthermore, Calo et al. (2012) state that Pinus levels of $10 \%$ might still be representative of long-distant transport because the species is a known producer of large quantities of well-dispersed pollen, therefore its pollen can be found even if the plant is not locally abundant. The origin of this Pinus pollen might not be Sicily or mainland Europe because Pinus (along with Corylus, Alnus, and Ostrya) has been documented to be on the island prior to the Holocene, in Pleistocene deposits (Hunt, 1997). Therefore this $10 \%$ increase at Burmarrad might be indicative of Pinus either now growing in small communities within the catchment area or perhaps in larger communities elsewhere on the archipelago.
In neighbouring Sicily, Pinus levels increase at a similar time at Lago Preola (Calò et al., 2012) and Gorgo Basso (Tinner et al., 2009). However, Carroll et al. (2012) recorded considerably more Pinus around this time $(3900 \mathrm{cal}$ BP onwards) within the same catchment area (reaching levels close to $80 \%$ ) although they suggest that this may be due to infilling of a former dredged channel (mid-19th century) rather than indicative of local vegetation at this time.

In addition, towards the middle of the Bronze Age period, there is a gradual decline in nitrophilous and pastoral taxa (Fig. 3), perhaps indicating a reduction in the amount of livestock within the catchment area. On the other hand, there is an increase in Poaceae as well as a considerable rise in Euphorbia. This latter taxon (along with Kickxia, Papaver rhoeas-group, Sinapis, Scleranthus, and Valerianella) is considered one of the classic indicators of cultivated areas in southern Europe (Brun et al., 2007). Therefore the Burmarrad area, while remaining a generally open landscape, may well have transformed from a predominately grazed area to a more cultivated one from the middle of the Bronze Age period onwards. Marriner et al. (2012) suggest that by around $3000 \mathrm{cal} \mathrm{BP}$ the Burmarrad ria had reduced to $0.9 \mathrm{~km}^{2}$ $(50 \%$ smaller than its $7000 \mathrm{cal}$ BP maximum marine transgression) providing a fertile deltaic floodplain for food production. Further supporting the suggestion of agricultural activity at this time are the silo-piths found within the hilltop settlements (Buhagiar, 2007). These provide indirect evidence that the amount of agricultural production was great enough to enable food storage to take place during this time. In Sicily, the evergreen vegetation decreased from 4500 to 3700 cal BP (such as at Biviere di Gela, Gorgo Basso, and Lago Preola; Fig. 1a), and a similar reduction can be observed within the Burmarrad catchment area. These sites in Sicily then record a recovery of evergreen taxa between 3700 and $2600 \mathrm{cal} \mathrm{BP}$. Almost synchronously, an increase is noted at around $3680 \mathrm{cal}$ BP in NW Malta. Unfortunately, the Burmarrad core has a break in the record just after this date, though it may be reasonable to suggest that a similar recovery period to Sicily occurred on the archipelago.

\subsubsection{Historical period}

The BM2 core sequence (Fig. 7) covers the first three phases of the historical period: Phoenician 2750-2430 BP, Punic 2430-2168 BP, and Roman 2168-1404 BP (Pace, 2004), although palynological data are currently only available for the period 1972-173 cal BP. At the beginning of the second Punic War the islands changed from Carthaginian to Roman rule, forming part of the Sicilian province (Bonanno, 2005). However, for about the first three hundred years the Punic culture, detectable in pottery styles and inscriptions, persisted (Blouet, 2007). Seventeen Roman period sites have been linked to the production and exportation of olive oil on the islands (Gambin, 2005), along with extensive port remains, such as quays and various buildings including ware- 
houses, around the Marsa area (Gambin, 2004/5), being in close proximity to the Grand Harbour, a naturally sheltered ria. Following Roman occupation in $2168 \mathrm{BP}$, archaeological remains and textual evidence both suggest that Malta was producing refined textiles and that some islanders were living in sophisticated dwellings such as a typical domus located in Rabat (Bonanno, 2005). The Burmarrad area also has archaeological evidence of Roman occupation. Evidence includes large oil-producing Roman villas (San Pawl Milqi and Bidnija), burial complexes (Bonanno, 2005), along with ceramic deposits datable to the Punico-Roman period from the silted ancient harbour (Gambin, 2005).

The last part of the core sequence for the Burmarrad plain dates to the mid-Roman phase (1972-1730 cal BP). The landscape in the catchment area at this time appears relatively open - Pinus levels have reduced, and NAP taxa are high, with a marked peak in Cichorioideae, Brassicaceae, and Cerealia-type, as well as smaller increases in Triticumtype and Plantago-type. An increase in agricultural activity within this area is supported by the presence of these cultivated crop and associated ruderal taxa. Marriner et al. (2012) conclude that around this time a large part of the area had become a well-developed fertile deltaic plain, therefore it is very likely that it was used for cultivation purposes. These crop taxa are generally considered to have poor dispersal, being under-represented (though present), even when near cultivated land (Brun et al., 2007; Behre, 1981).

When interpreting pollen data, possible long-distance transport, including that of cereals, should be considered (Birks and Birks, 1980; Court-Picon et al., 2005). Another consideration regarding Poaceae, including cereals and other crop species, is that pollen dispersal and its potential deposition is dependent on harvesting methods (Hall et al., 2013). Furthermore, it has been suggested by López-Merino et al. (2010) that crop cultivation may decrease the herbaceous plant community abundance, while abandonment can have the opposite effect. This increase in cultivated species and corresponding decrease in herbaceous taxa can be noted in the pollen record of Burmarrad during this time, although attention must be placed on the over- or under-representation situation caused by a plant's life cycle. Under-represented taxa, such as cereals, are considered to produce low quantities of pollen that are poorly dispersed (Court-Picon et al., 2006). This can cause over-representation of extra-local and regional pollen that is anemophilous in nature. Furthermore, pollen production of local Poaceae taxa in intensive livestock areas has been suggested to be low due to overgrazing (Hjelle, 1998; Mazier et al., 2006), which possibly would also allow for over-representation of extra-local and regional pollen, although Ejarque et al. (2011) observed contrasting results in their modern pollen-rain study.

Another notable increase is that of Olea, peaking at ca. $1800 \mathrm{cal}$ BP. Although not as large as the one recorded in the Temple period it reaches nearly $10 \%$. This level appears consistent with Di Rita and Magri's (2009) research from an early period (3500-2700 cal BP) that finds Olea percentages never exceeding $10 \%$ in sites within the evergreen vegetation belt in Italy and the Balkans (such as Lago Battaglia, Caroli and Caldara, 2007, Lago dell' Accesa, Lake Voulkaria, and Malo Jezero). Olea is considered an emblematic plant of the Mediterranean (Kaniewski et al., 2012; Di Rita and Melis, 2013) acting as a bio-indicator to define the limits of this region's vegetation (Grove and Rackham, 2001; Carrión et al., 2010; Roberts et al., 2011) being both drought-tolerant and cold-intolerant (Collins et al., 2012), though its adequacy as a true bio-indicator has been questioned due, in part, to its cultivation (Blondel et al., 2010). Olea is a good producer and disperser of pollen (van Zeist et al., 2009). Its pollen can be found in the surface samples even when the plant is not present in the region (Canellas-Bolta et al., 2009; Joannin et al., 2012), though other researchers (Davis, 1994; Stevenson, 1981 ) note that it may only be a good producer but a poor disperser. It has been observed that Olea pollen can vary greatly in modern surface samples within olive stands, such as between 3 and $40 \%$ (van Zeist and Bottema, 1991) and 7.6 and $56.4 \%$ (Florenzano, 2013). In fact Florenanzo (2013) notes that this level decreased to just $2.1-7.6 \%$ at $500 \mathrm{~m}$ from the stand. Djamali et al. (2015) suggest that their SW Iran Olea levels, reaching $8.2 \%$, indicate small-scale olive groves distributed over the catchment area. With this is mind, the origin of BM2's Olea increase, if not from Burmarrad, is most likely still from within the islands. However, Carroll et al. (2012) did not record Olea in their Salina Bay sequence in any great quantities and it was not noted as present during this particular phase (possible explanations for the latter site provided in Sect. 5.1.2).

The interpretation that Olea was present on the island, possibly within the Burmarrad area, is based both on the palynological evidence provided in BM2 as well as from archaeological and geoarchaeological evidence as stated by Gambin $(2004,2005,2012)$ and Bruno (2007), which suggests that Burmarrad was an area of olive production during the Roman period. The Roman villa of San Pawl Milqi, situated within the catchment area, has substantial structures for olive pressing and oil production (Cefai et al., 2005). Also supporting this idea is the nearby presence of an ancient grove that is situated next to a surveyed but unexcavated Roman villa (Docter et al., 2012). Furthermore, the scale and quantity of these archeological remains suggest that the oil production exceeded the needs of the local population (Gambin, 2005; Marriner et al., 2012). This rise in Olea cultivation in the Roman period corresponds well with that observed in Tripolitania, Libya (Barker et al., 1996), as well as other areas such as Spain (Pantaléon-Cano et al., 2003) and the Levant (Kaniewski et al., 2014; Litt et al., 2012). Di Rita and Magri (2009, p. 304) note that the "Roman occupation coincided with a modest diffusion of Olea"; they suggest that between 2500 and 1500 cal BP the climate conditions in southern Italy were not so advantageous for olive cultivation (whereas the Bronze Age people benefited from plentiful wild olive pro- 
ductions), though more generally, Jalut et al. (2009) propose that from $3600 \mathrm{BP}$ the increase in Olea is due to drier conditions making its cultivation favourable. The interpretation in the case of Burmarrad is that the Olea increase was human influenced with favourable local growing conditions.

With regard to Olea expansion at this time in other localities, this increase is not recorded in the southern Sicilian sites, while in Greece Van Overloop (1986) observes the Roman period having a general decrease in AP taxa (including Olea) with increasing steppe vegetation. On the other hand, increases in Olea were recorded in western Mediterranean sites such as southern Spain (Pantaléon-Cano et al., 2003) and on the eastern edges of the region, such as the Levant (Kaniewski et al., 2014; Litt et al., 2012).

Other notable changes include higher levels of microcharcoal, compared to the Bronze Age, which can also be observed at Lago Preola, Sicily (Calò et al., 2012). Additionally, there is the highest peak of both Glomus and Cichoriaceae taxa in the whole sequence. Cichorioideae is used with caution - it is known to be over-represented in pollen diagrams, especially when found in badly preserved material (Mercuri et al., 2006), due to Di Rita and Magri (2009). However, recent research by Florenzano et al. (2015) suggests that Cichorieae can be used as an indicator of some types of primary open habitats as well as secondary pasture sites. In BM2, the other pollen and spores encountered in these samples were of good preservation, so this particular issue can be discounted. Furthermore, Mercuri et al. (2006) suggest that the presence of cereal and (abundant) Cichorioideae pollen together can provide evidence for human settlements and their associated crop fields and pastures. These two taxa are at their most abundant at this time in Burmarrad and therefore very likely indicate an anthropogenic signal. With regard to Glomus, a known indicator of soil disturbance, this high level might suggest an increase in humaninfluenced erosional activity. This is concurrent with continued infilling of the ria (Marriner et al., 2012). Wilson (2013) notes that Roman scholars (such as Pausanias, AD160) were aware of "the effects of agriculture on increasing erosion and the concomitant downstream deposit of alluvial fans".

\subsection{An interpretation of climatic change}

The Holocene climate has fluctuated both spatially and temporally on a global scale (Mayewski et al., 2004) as well as within the Mediterranean Basin (e.g. Brayshaw et al., 2011; Jalut et al., 2009; Magny et al., 2002, 2011; Roberts et al., 2011; Mauri et al., 2015). Human impacts have affected the natural vegetation of the Mediterranean since the midHolocene, but disentangling the climatic and anthropogenic causes of vegetation change is complex. Our climatic reconstruction seems consistent with independent records from the Mediterranean such as lake levels from Sicily (Fig. 8) or speleothems from Israel (Magny et al., 2012; Bar-Matthews and Ayalon, 2011), and large-scale paleoclimate reconstruc- tion (Mauri et al., 2015). This reconstruction provides valuable insight into the palaeoclimate of this centrally situated archipelago between 7280 and $1730 \mathrm{cal} \mathrm{BP}$, allowing for comparisons to be made with other reconstructions undertaken within the Mediterranean region (Figs. 8 and 9).

\subsubsection{Temperature}

The trends observed within the Burmarrad sequence are comparable to other southern Mediterranean climate reconstructions, particularly Sicilian and southern Italian mainland sites (Peyron et al., 2013). The temperature for Malta is slightly warmer than that recorded at Lago Pergusa, Sicily (Sadori et al., 2013b), which is situated at a higher altitude (667 $\mathrm{m}$ a.s.1.); however, the overall pattern of fluctuation is similar (Fig. 8). This difference may be due in part to the more southerly latitude of the Maltese islands. Orography is another factor that may create both regional and local variances in Mediterranean heat wave, wind, and cyclonic activity (Gladich et al., 2008; Lionello et al., 2006; Sotillo et al., 2003). The Maltese archipelago's relatively small area and low-lying terrain differ greatly from Sicily's larger and much more mountainous area.

The reconstructed MTCO temperature for Burmarrad can be summarized as warm in the early Holocene, followed by instability after 4800 cal BP, particularly between 4100 and $3700 \mathrm{cal} \mathrm{BP}$ with a minimum at $7^{\circ} \mathrm{C}$. This period of fluctuation between 4400 and 3700 cal BP coincides with rapid climate change (RCC) events on a global scale noted between 4200 and 3800 BP (Mayewski et al., 2004), as well as regionally within the Mediterranean (Combourieu Nebout et al., 2013; Jalut et al., 2009; Magny and Combourieu Nebout, 2013). During the Holocene, the development of complex societies within the Mediterranean region have been noted to be "coincident with and partly stimulated by these climatic changes" (Roberts et al., 2011). With respect to Malta, this period saw the onset of the Bronze Age and its notable differences from the previous temple-building period not only culturally but also in vegetation and increased soil erosion (Sect. 5.1.4). We also cannot exclude for this period a possible bias in our climate reconstructions due to the increasing human impact.

\subsubsection{Precipitation}

Peyron et al. (2013) propose a north-south divide for Italy, similar to that seen in the eastern Mediterranean (Dormoy et al., 2009; Kotthoff et al., 2008, 2011), which supports the mid-Holocene opposing summer precipitation hypothesis for the Mediterranean; that of a reduced summer precipitation for northern sites (above $40^{\circ} \mathrm{N}$ ) and a maximum for southern sites (below $40^{\circ} \mathrm{N}$ ) for the early to mid-Holocene period. The early Holocene reconstruction from Malta suggests a gradual increase in summer precipitation from ca. $7000 \mathrm{cal} \mathrm{BP}$, peaking at around $5300 \mathrm{cal} \mathrm{BP}$. Within Sicily, Frisia et al. (2006) 


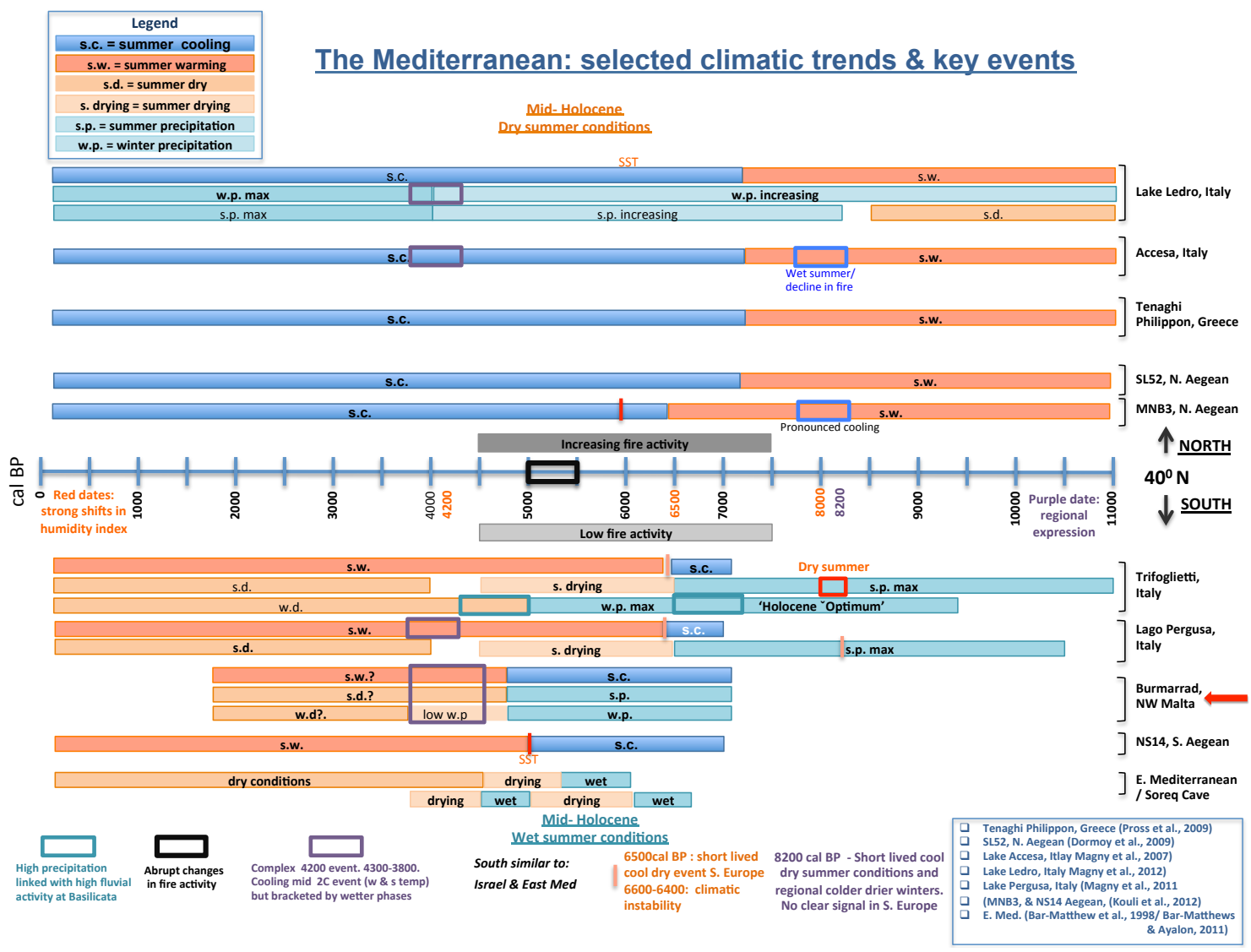

Figure 9. Synthesis of general trends and key events indicating Malta's reconstructed climatic position (all data, except Burmarrad, from Peyron et al., 2013).

suggest that between 7500 and $6500 \mathrm{BP}$ multi-decadal dry spells created hydrologically unstable conditions that probably favoured the development of Neolithic agriculturalism. In Malta, the first evidence of settlement is dated to around 7200-7000 cal BP (Trump, 2002), which includes archaeological as well as palynological indications of agricultural activity (Sect. 5.1.1). In the late Holocene, the summer precipitation in the Burmarrad catchment area decreases to below previous levels, but can be potentially biased by human impact. The only anomaly is the 1700 cal BP increase in summer precipitation at the very end of the sequence; further investigation is required to explain the cause of this event. This rise at $1700 \mathrm{cal} \mathrm{BP}$ does however appear to exhibit a similarity with Jalut et al.'s (2009) observation that within the western Mediterranean an arid phase occurred between 2850 and $1730 \mathrm{cal} \mathrm{BP}$, which they point out correlates to an eastern Mediterranean dry episode 3000-1700 cal BP. More data from Malta are required either side of this $1700 \mathrm{cal} \mathrm{BP}$ date to verify this similarity.

Burmarrad's winter precipitation pattern and quantity is, on the whole, comparable with Lago Pergusa (Fig. 8). Both areas are subject to an increase in winter precipitation between 7000 and $5500 \mathrm{cal} \mathrm{BP}$, followed by a slight decrease until just before $5000 \mathrm{calBP}$. Djamali et al. (2012) suggest that the early Holocene (7350-6960 cal BP) was relatively dry, favouring steppe vegetation in the Maltese islands (as well as some other Mediterranean sites). This was most probably due to the indirect effect of the subtropical monsoon intensifications, with the maximum moisture availability occurring during the time of Pistacia expansion. At $5000 \mathrm{cal} \mathrm{BP}$, another increase occurs, though to a greater extent in Lago Pergusa. From 5000 until 4500 cal BP, both sites experience a decrease followed by a period of instability between 4500 and 3700 cal BP. In the Pergusa site this instability continues to about $3000 \mathrm{cal} \mathrm{BP}$; however, it does not feature in the Burmarrad core due to a gap in the sequence. This phase coincides with the $4400-3500$ cal BP drier phase noted at Lago Trifoglietti (Joannin et al., 2012). Both sites then experience a decrease in precipitation between 2000 and 1700 cal BP, again coinciding with drier phases noted at Lago Trifoglietti and within the Mediterranean as a whole (Jalut et al., 2009).

Based on results from Sicily's Lago Pergusa (pollenbased) and Lago Preola (lake-level), Magny et al. (2011) describe the pattern of Holocene precipitation as having a maximum winter and summer wetness between 9800- 
4500 cal BP, followed by declining winter and summer wetness. This is largely consistent with findings from Burmarrad. These changing moisture levels during the Holocene have been linked to significant societal changes. Sadori et al. (2015b) propose that periods of increased humidity, over the last 2000 years, coincided with both agricultural and demographic expansions. While Weiss and Bradley (2001) suggest that, around $4250 \mathrm{BP}$, a number of cultures were at their economic peak, such as Mesopotamia's Akkadian empire, Egypt's Old Kingdom civilization and Palestine, Greece, and Crete's Early Bronze societies; however, these once flourishing areas declined rapidly after $4150 \mathrm{BP}$ possibly due to severe drought and cooling. The event has been recorded elsewhere in the world and seems to have acted at a global scale (Booth et al., 2005). The impact of drought events on the human socio-economy, and the consequent impacts on the landscape, should thus not be underestimated, as has been recently suggested by Sharifi et al. (2015) for the continental Middle East. These increases in aridity not only affect the vegetation communities directly but also indirectly by altering the anthropogenic pressure on the local landscape, both directly in those regions, as well as wherever the displaced people migrate. This combined effect is not confined to the eastern Mediterranean at this time. Closer to the Maltese archipelago, Noti et al. (2009) suggest that at Gela di Biviere, Sicily, between 5000 and 4000 cal BP, the anthropogenic impact occurring on the landscape is probably influenced by the climatic changes.

As well as the north-south divide, there are also eastwest differences in moisture that have been recorded in the Mediterranean during the early Holocene (Roberts et al., 2011; Vannière et al., 2011), whereby during the early Holocene the northeastern region underwent a period of increased winter precipitation up until $6000 \mathrm{BP}$ followed by a decline, whereas south of the Dead Sea, Hunt et al. (2007) suggest a general decrease in precipitation through the early to mid-Holocene, and in the western region, though less pronounced, the maximum increases occurred between 6000 and $3000 \mathrm{BP}$ before declining to current levels (Roberts et al., 2011); see Zielhofer and Faust (2008) for mid-late Holocene fluctuations recorded in Tunisia. Therefore, given Malta's central location, finding its "climatic" position poses an interesting task. The first part is fairly simple: lying below $40^{\circ} \mathrm{N}$ (Fig. 9) its climatic reconstruction is quite synchronous with other southern localities (Peyron et al., 2013); however, its east-west position is more debatable and beyond the scope of this paper, though with changing climatic drivers, such as the North Atlantic Oscillation (NAO) and subtropical monsoon system and their associated moisture levels (Morley et al., 2014), the archipelago's "position" might possibly vary throughout the Holocene as the system fluctuates.

\section{Conclusions}

This paper presents vegetation dynamics from ca. 7280 to 1730 cal BP for Burmarrad in Northwest Malta, along with a pollen-based climate reconstruction for this archipelago. The vegetation changes recorded within the catchment area correspond well with those observed in the shorter early to mid-Holocene sequence of BM1 core, as well as those from neighbouring southern sites in coastal Sicily. If vegetation changes in Burmarrad are similar to those in coastal Sicily then it may be possible to infer similarities to other areas within Malta itself, or at least it can be "reasonably assumed", though such assumptions would have to be tested.

This inference might also be supported by the fact that Malta has a relatively low topographic variability and is almost completely located within the same bioclimatic and vegetation belt (Thermo-Mediterranean) similar to that of coastal Sicily. In such a context, the slightly varying responses of biomes/vegetations to hydroclimatic trends as observed in highland vs. lowland Sicily (e.g. in Pergusa versus Gorgo Basso) would not be observed in Malta.

The climatic reconstruction is based on the pollen record from this northwestern region; however, the island is relatively small in size and therefore our interpretations can probably be taken for the area as a whole. The reconstruction also provides strong correlation with climatic reconstructions conducted for southern Mediterranean sites. The main findings are as follows.

Between ca. 7280 to 6700 cal BP (early Neolithic period) the results record an initially open landscape at the site, surrounding a large palaeobay, with arboreal pollen taxa at their lowest levels.

From ca. 6700 cal BP dense Pistacia scrubland developed, similar to that observed in the BM1 core, as well as at southern Sicilian sites at around this time. This predominantly Pistacia scrubland lasted into the Temple period $(4900$ cal BP), whereafter it decreased and became more mixed with increasing levels of Olea. The climate reconstruction points to a more moist period during the Pistacia expansion.

From ca. $4450 \mathrm{cal}$ BP the landscape became more open again, coinciding with the start of the Bronze Age on the archipelago. Notably, fire events also increase during this period as do indications of increased soil erosion (Pseudoschizaea and Glomus taxa); while the palaeobay undergoes infilling, becoming about half its original size by $3000 \mathrm{cal} \mathrm{BP}$. Towards the middle of the Bronze age, there is an increase in both nitrophilous plant taxa and coprophilous fungi (such as Sporormiella) indicative of grazing activity. This period coincides with increased climatic instability (between 4600 and $3700 \mathrm{cal} \mathrm{BP}$ ) which is followed by a gradual decrease in summer moisture availability.

During the early Roman occupation period the landscape is still fairly open with an increase in Olea corresponding to archaeological evidence of a Roman port and agricultural ac- 
tivity in the area, such as rural Roman villas with artefacts relating to olive production. There is also an increase in cultivated crop taxa and associated ruderal species, along with a rise in fire events. There is reduced precipitation at this time, similar to that noted in sites in southern Italy as well as a generally drier trend recorded within the Mediterranean region.

Through continued interdisciplinary research both on this archipelago and other Mediterranean locations more precise reconstructions of vegetation assemblages and climatic variations can be provided for the Holocene. These robust and comprehensive data sets can provide information on the various processes and drivers influencing not only past but also present and future landscapes. The question of Holocene climate- or human-driven environmental change remains a tricky one. An alternative approach might be to consider these two factors, which Sadori et al. (2013) emphasize have a "synergy", as interactive or dual-action for at least the midHolocene onwards; in this way it might bring us closer to a better understanding and appreciation of the continually evolving Mediterranean "living mosaic" landscape.

Acknowledgements. The authors would like to thank Nicholas Vella from the Department of Archaeology at the University of Malta for the kind use of the Zeiss Light Microscope, Edwin Lanfranco for sharing his extensive knowledge on local vegetation, Dr Saviour Formosa for the DTM layer of NW Malta, and Dr Lyudmila Shumilovskikh (IMBE) for her expertise in NPP identification. This research was partially funded by the ANR Paleomed project (09-BLAN-0323-204 01).

Edited by: N. Combourieu Nebout

\section{References}

Anderson, E. W.: The wied: a representative Mediterranean landform, GeoJournal, 41, 111-114, 1997.

Andrieu, V., Brugiapaglia, E., Cheddadi, R., Reille, M., Beaulieu, J.-L., and Barbero, M.: A computerized data base for the palynological recording of human activity in the Mediterranean basin, in: Environmental Reconstruction in Mediterranean Landscape Archaeology, edited by: Leveau, P., Walsh, K., Trement, F., and Barker, G., Oxbow Books, Oxford, 17-24, 1999.

Avramidis, P., Geraga, M., Lazarova, M., and Kontopoulos, N.: Holocene record of environmental changes and palaeoclimatic implications in Alykes Lagoon, Zakynthos Island, western Greece, Mediterranean Sea, Quatern. Int., 293, 184-195, 2013.

Barker, G., Gilbertson, D., Jones, B., and Mattingly, D.: Farming the Desert, The UNESCO Libyan Valleys Archaeological Survey, Paris, UNESCO Publishing, Tripoli, Department of Antiquities, London, Society for Libyan Studies, edited by: Barker, G., Synthesis, Vol. 1, 404 pp., 1996.

Bar-Matthews, M. and Ayalon, A.: Mid-Holocene climate variations revealed by high-resolution speleothem records from Soreq Cave, Israel and their correlations with cultural changes, Holocene, 21, 163-172, 2011.
Bar-Matthews, M., Ayalon, A., and Kaufman, A.: Middle to Late Holocene (6500 yr period) paleoclimate in the eastern Mediterranean region from stable isotopic composition of speleothems from Soreq Cave, Israel, in: Environment and society in timesof climate change, edited by: Issar, A. and Brown, N., Kluwer Academic, Dordrecht, 203-214, 1998.

Bartlein, P. J., Harrison, S. P., Brewer, S., Connor, S., Davis, B. A. S., Gajewski, K., Guiot, J., Harrison-Prentice, T. I., Henderson, A., Peyron, O., Prentice, I. C., Scholze, M., Seppä, H., Shuman, B., Sugita, S., Thompson, R. S., Viau, A. E., Williams, J., and Wu, H.: Pollen-based continental climate reconstructions at 6 and 21 ka: a global synthesis, Clim. Dynam., 37, 775-802, doi:10.1007/s00382-010-0904-1, 2011.

Bates, J. W.: Mineral nutrition and substratum ecology, in: Bryophyte Biology, edited by: Goffinet, B. and Shaw, A. J., Cambridge University Press, Cambridge, 299-356, 2009.

Beaulieu, J.-L., Miras, Y., Andrieu-Ponel, V., and Guiter, F.: Vegetation dynamics in north-western Mediterranean regions: instability of the Mediterranean bioclimate, Plant Biosyst., 139, 114126, doi:10.1080/11263500500197858, 2005.

Beer, R., Tinner, W., Carraro, G., and Grisa, E.: Pollen representation in surface samples of the Juniperus, Picea and Juglans forest belts of Kyrgyzstan, central Asia, Holocene, 17, 599-611, doi:10.1177/0959683607078984, 2007.

Behre, K.-E.: The interpretation of anthropogenic indicators in pollen diagrams, Pollen et Spores, 23, 225-245, 1981.

Behre, K.-E.: Some reflections on anthropogenic indicators in the record of prehistoric occupation phases in pollen diagrams from the Near East, in Man's role in the shaping of the eastern Mediterranean landscape, edited by: Bottema, S., Entjes-Nieborg, G., and van Zeist, W., Balkema, Rotterdam, 219-237, 1990.

Bellini, C., Mariotti-Lippi, M., and Montanari, C.: The Holocene landscape history of the NW Italian coasts, Holocene, 8, 11611172, 2009.

Benton, M. and Harper, D. A. T.: Introduction to Paleobiology and the Fossil Record, Wiley-Blackwell, Oxon, 608 pp., 2009.

Berger, J. F. and Guilaine, J.: The $8200 \mathrm{cal}$ BP abrupt environmental change and the Neolithic transition: a Mediterranean perspective, Quatern. Int., 200, 31-49, doi:10.1016/j.quaint.2008.05.013, 2009.

Beug, H.-J.: Leitfaden der Pollenbestimmung fur Mitteleuropa und angrenzende Gebiete, Pfeil, München, 2004.

Birks, H. J. B.: Strengths and weaknesses of quantitative climate reconstructions based on late-Quaternary biological proxies, Open Ecol. J., 3, 68-110, doi:10.2174/1874213001003020068, 2011.

Blaauw, M.: Methods and code for "classical" age-modelling of radiocarbon sequences, Quat. Geochronol., 5, 512-518, 2010.

Blondel, J., Aronson, J., Bodiou, J.-Y., and Boeuf, G.: The Mediterranean Region - Biological Diversity in Space and Time, 2nd edn., Oxford University Press, Oxford, 2010.

Blouet, B.: The Story of Malta, revised Edn., Allied Publications, Malta, 2007.

Bonanno, A.: Malta: Phoenician, Punic and Roman, Midsea Books, Malta, 2005.

Booth, R. K., Jackson, S. T., Forman, S. L., Kutzbach, J. E., Bettis, E. A., Kreig, J., and Wright, D. K.: A severe centennial-scale drought in midcontinental North America 4200 years ago and apparent global linkages, Holocene, 15, 321-328, 2005. 
Boros, A., Járai-Komlódi, M., Toth, Z., and Nilsson, S.: An Atlas of Recent European Bryophyte Spores, Scientia Publishing, Budapest, 321 pp., 1993.

Bottema, S. and Sarpaki, A.: Environmental change in Crete: a 9000-year record of Holocene vegetation history and the effect of the Santorini eruption, Holocene, 13, 733-749, doi:10.1191/0959683603hl659rp, 2003.

Brayshaw, D. J., Rambeau, C. M. C., and Smith, S. J.: Changes in Mediterranean climate during the Holocene: insights from global and regional climate modelling, Holocene, 21, 15-31, doi:10.1177/0959683610377528, 2011.

Brewer, S., Guiot, J., Sánchez-Goñi, M. F., and Klotz, S.: The climate in Europe during the Eemian: a multi-method approach using pollen data, Quaternary Sci. Rev., 27, 2303-2315, doi:10.1016/j.quascirev.2008.08.029, 2008.

Briggs, D.: Plant Microevolution and Conservation in HumanInfluenced Ecosystems, Cambridge University Press, Cambridge, 598 pp., 2009.

Broodbank, C.: The origins and early development of Mediterranean maritime activity, J. Mediterr. Archaeol., 19, 199-230, doi:10.1558//jmea.2006.v19i2.199, 2006.

Broodbank, C.: The Making of the Middle Sea: a History of the Mediterranean from the Beginning to the Emergence of the Classical World, Thames and Hudson, London, 672 pp., 2013.

Brun, C., Dessaint, F., Richard, H., and Bretagnolle, F.: Arableweed flora and its pollen representation: a case study from the eastern part of France, Rev. Palaeobot. Palyno., 146, 29-50, doi:10.1016/j.revpalbo.2007.02.001, 2007.

Bruno, B.: Roman and Byzantine Malta - Trade and Economy, Midsea Books, Malta, 2007.

Buhagiar, K.: Bahrija: its archaeological significance, Melita Historia, XIV, 357-374, 2007.

Buhagiar, M.: Essays on the Archaeology and Ancient History of the Maltese Islands: Bronze Age to Byzantine, Midsea Books, Malta, 2014.

Calò, C., Henne, P. D., Curry, B., Magny, M., Vescovi, E., La Mantia, T., Pasta, S., Vannière, B., and Tinner, W.: Spatio-temporal patterns of Holocene environmental change in southern Sicily, Palaeogeogr. Palaeocl., 323-325, 110-122, doi:10.1016/j.palaeo.2012.01.038, 2012.

Canellas-Bolta, N., Rull, V., Vigo, J., and Mercade, A.: Modern pollen-vegetation relationships along an altitudinal transect in the central Pyrenees (southwestern Europe), Holocene, 19, 1185-1200, doi:10.1177/0959683609345082, 2009.

Caroli, I. and Caldara, M.: Vegetation history of Lago Battaglia (Eastern Gargano coast, Apulia Italy) during the middle-late Holocene, Veg. Hist. Archaeobot, 16, 317-327, 2007.

Carrión, J. S.: Patterns and processes of late Quaternary environmental change in a montane region of southwestern Europe, Quaternary Sci. Rev., 21, 2047-2066, 2002.

Carrión, J. S., Fuentes, N., González-Sampériz, P., Sánchez Quirante, L., Finlayson, J. C., Fernández, S., and Andrade, A.: Holocene environmental change in a montane region of southern Europe with a long history of human settlement, Quaternary Sci. Rev., 26, 11-12, 1455-1475, doi:10.1016/j.quascirev.2007.03.013, 2007.

Carrión, J. S., Fernández, S., González-Sampériz, P., GilRomera, G., Badal, E., Carrión-Marco, Y., López-Merino, L., López-Sáez, J. A., Fierro, E., and Burjachs, F.: Expected trends and surprises in the Lateglacial and Holocene vegetation history of the Iberian Peninsula and Balearic Islands, Rev. Palaeobot. Palyno., 162, 458-475, doi:10.1016/j.revpalbo.2009.12.007, 2010a.

Carrión, Y., Ntinou, M., and Badal, E.: Olea europaea L. in the North Mediterranean Basin during the Pleniglacial and the Early-Middle Holocene, Quaternary Sci. Rev., 29, 952-968, doi:10.1016/j.quascirev.2009.12.015, 2010b.

Carroll, F. A., Hunt, C. O., Schembri, P. J., and Bonanno, A.: Holocene climate change, vegetation history and human impact in the Central Mediterranean: evidence from the Maltese Islands, Quaternary Sci. Rev., 52, 24-40, doi:10.1016/j.quascirev.2012.07.010, 2012.

Cassar, L. F., Conrad, E., and Schembri, P. J.: The Maltese Archipelago, in: Mediterranean Island Landscapes, edited by: Vogiatzakis, I. N., Pungetti, G., and Mannion, A. M., Natural and Cultural Approaches, Springer, Dordrecht, 297-322, 2008.

Cefai, S., Cassar, J., and Locatelli, D.: San Pawl Milqi, Burmarrad, Malta - presentation of a multi-cultural site in a changing landscape, in: Proceedings of the ICOMOS Scientific Symposium: Monuments and Sites in their Setting - Conserving Cultural Heritage in Changing Townscapes and Landscapes, Section III: Evolving Townscapes and Landscapes within their Settings: Managing Dynamic Change, 17-24 October 2005, Xi'an, China, Section III no. 46, 2005.

Chetcuti, D., Buhagiar, A., Schembri, P. J., and Ventura, F.: The Climate of the Maltese Islands: a review, Malta University Press, Msida, Malta, 1992.

Colledge, S. and Conolly, J. (Eds.): The Origins and Spread of Domestic Plants in Southwest Asia and Europe, Left Coast Press, Walnut Creek (CA), 2007.

Collins, P. M., Davis, B. A. S., and Kaplan, J. O.: The mid-Holocene vegetation of the Mediterranean region and southern Europe, and comparison with the present day, J. Biogeogr., 39, 1848-1861, doi:10.1111/j.1365-2699.2012.02738.x, 2012.

Combourieu Nebout, N., Peyron, O., Bout-Roumazeilles, V., Goring, S., Dormoy, I., Joannin, S., Sadori, L., Siani, G., and Magny, M.: Holocene vegetation and climate changes in the central Mediterranean inferred from a high-resolution marine pollen record (Adriatic Sea), Clim. Past, 9, 2023-2042, doi:10.5194/cp9-2023-2013, 2013.

Costantini, E. A. C., Priori, S., Urban, B., Hilgers, A., Sauer, D., Protano, G., Trombino, L., Hülle, D., and Nannoni, F.: Multidisciplinary characterization of the middle Holocene eolian deposits of the Elsa River basin (central Italy), Quatern. Int., 209, 107-130, doi:10.1016/j.quaint.2009.02.025, 2009.

Court-Picon, M., Buttler, A., and Beaulieu, J.-L.: Modern pollenvegetation relationships in the Champsaur Valley (French Alps) and their potential in the interpretation of fossil pollen records of past cultural landscapes, Rev. Palaeobot. Palyno., 135, 13-39, 2005.

Court-Picon, M., Buttler, A., and Beaulieu, J.-L.: Modern pollen/vegetation/land-use relationships in mountain environments: an example from the Champsaur Valley (French Alps), Veg. Hist. Archaeobot., 15, 151-168, doi:10.1007/s00334-0050008-8, 2006.

Cugny, C.: Apports des microfossiles non-polliniques a l'histoire du pastoralisme sur le versant nord Pyrene en entre referentiels 
actuels et reconstitution du passe, Unpublished $\mathrm{PhD}$, Universite Toulouse 2, Le Mirail, 2011.

Cugny, C., Mazier, F., and Galop, D.: Modern and fossil non-pollen palynomorphs from the Basque Mountains (western Pyrenees, France): the use of coprophilous fungi to reconstruct pastoral activity, Veg. Hist. Archaeobot., 19, 391-408, doi:10.1007/s00334010-0242-6, 2010.

Cushing, E. J.: Evidence for differential pollen preservation in late Quaternary sediments in Minnesota, Rev. Palaeobot. Palyno., 4, 87-101, 1967.

Davis, B.: Palaeolimnology and Holocene Environmental change from endoreic NE Spain, Unpublished PhD, Newcastle University, Newcastle, 1994.

Delhon, C., Thiébault, S., and Berger, J. F.: Environment and landscape management during the Middle Neolithic in southern France: evidence for agro-sylvo-pastoral systems in the Middle Rhone Valley, Quatern. Int., 200, 50-65, doi:10.1016/j.quaint.2008.05.008, 2009.

Di Rita, F. and Magri, D.: Holocene drought, deforestation and evergreen vegetation development in the central Mediterranean?: a 5500 year record from Lago Alimini Piccolo, Apulia, southeast Italy, Holocene, 2, 295-306, 2009.

Di Rita, F. and Magri, D.: An overview of the Holocene vegetation history from the central Mediterranean coasts, J. Mediterr. Earth Stud., 4, 35-52, doi:10.3304/JMES.2012.003, 2012.

Di Rita, F. and Melis, R. T.: The cultural landscape near the ancient city of Tharros (central West Sardinia): vegetation changes and human impact, J. Archaeol. Sci., 40, 4271-4282, doi:10.1016/j.jas.2013.06.027, 2013.

Djamali, M., Gambin, B., Marriner, N., Andrieu-Ponel, V., Gambin, T., Gandouin, E., Lanfranco, S., Médail, F., Pavon, D., Ponel, P., and Morhange, C.: Vegetation dynamics during the early to mid-Holocene transition in NW Malta, human impact versus climatic forcing, Veg. Hist. Archaeobot., 22, 367-380, doi:10.1007/s00334-012-0380-0, 2012.

Djamali, M., Jones, M. D., Migliore, J., Balatti, S., Fader, M., Contreras, S., Hosseini, Z., Lahijani, H., Naderi, A. Shumilovskikh, L., Tengberg, M., and Weeks, L.: Olive cultivation in the heart of the Persian Achaemenid Empire: new insights into agricultural practices and environmental changes reflected in a late Holocene pollen record from Lake Parishan, SW Iran, Veg. Hist. Archaeobot., 1-15, doi:10.1007/s00334-015-0545-8, 2015.

Docter, R. F., Vella, N. C., Cutajar, N., Bonanno, A., and Pace, A.: Rural Malta: first results of the joint Belgo-Maltese survey project, Babesch, 87, 107-149, 2012.

Dormoy, I., Peyron, O., Combourieu Nebout, N., Goring, S., Kotthoff, U., Magny, M., and Pross, J.: Terrestrial climate variability and seasonality changes in the Mediterranean region between 15000 and 4000 years BP deduced from marine pollen records, Clim. Past, 5, 615-632, doi:10.5194/cp-5-615-2009, 2009.

Ejarque, A., Miras, Y., and Riera, S.: Pollen and non-pollen palynomorph indicators of vegetation and highland grazing activities obtained from modern surface and dung datasets in the eastern Pyrenees, Rev. Palaeobot. Palyno., 167, 123-139, doi:10.1016/j.revpalbo.2011.08.001, 2011.

Erdtman, G.: An Introduction to Pollen Analysis, Chronica Botanica Company, Waltham, Mass., 1943.

Estiarte, M., Peñuelas, J., López-Martínez, C., and Pérez-Obiol, R.: Holocene palaeoenvironment in a former coastal lagoon of the arid south eastern Iberian Peninsula: salinization effects on $\delta^{15} \mathrm{~N}$, Veg. Hist. Archaeobot., 17, 667-674, doi:10.1007/s00334-0080153-y, 2008.

Faegri, K. and Iversen, J.: Textbook of Pollen Analysis, IV edn., Blackburn Press, New Jersey, 2000.

Fenech, K.: Human Induced Changes in the Environment and Landscape of the Maltese Islands from the Neolithic to the 15th Century AD, BAR Internat Ser 1, 682, British Archaeological Reports, Oxford, 2007.

Finkelstein, I. and Langgut, D.: Dry climate in the Middle Bronze I and its impact on settlement patterns in the Levant and beyond?: new pollen evidence, J. Near Eastern Stud., 73, 2, 219-234, 2014.

Fletcher, W. J., Debret, M., and Sanchez Goñi, M. F.: Mid-Holocene emergence of a low-frequency millennial oscillation in western Mediterranean climate: implications for past dynamics of the North Atlantic atmospheric westerlies, Holocene, 23, 153-166, doi:10.1177/0959683612460783, 2013.

Florenzano, A.: Evoluzione di un paesaggio mediterraneo nella ricostruzione archeoambientale di siti lucani: evolution of a Mediterranean landscape as shown by the archaeoenvironmental reconstruction of Lucanian sites, $\mathrm{PhD}$ dissertation, Universita degli Studi di Modena e Reggio Emilia, Modena, 2013.

Florenzano, A., Marignani, M., Rosati, L. Fascetti, S., and Mercuri, A. M.: Are Cichorieae an indicator of open habitats and pastoralism in current and past vegetation studies?, Plant Biosyst. 149, 154-165, 2015.

Frisia, S., Borsato, A., Mangini, A., Spötl, C., Madonia, G., and Sauro, U.: Holocene climate variability in Sicily from a discontinuous stalagmite record and the Mesolithic to Neolithic transition, Quaternary Res., 66, 388-400, doi:10.1016/j.yqres.2006.05.003, 2006.

Galdies, C.: The Climate of Malta: Statistics, Trends and Analysis 1951-2010, National Statistics Office, Malta, 2011.

Gambin, T.: Islands of the Middle Sea: an archaeology of a coastline, in: Evolución paleoambiental de los puertos y fondeaderos antiguos en el Mediterráneo occidental, edited by: De Maria, L. and Turchetti, R., Rubbettino Editore, Soveria Mannelli, 127146, 2004.

Gambin, T.: Archaeological discoveries at Marsa over the centuries, Malta Archaeological Review, 7, 49-54, 2004/5.

Gambin, T.: The maritime landscapes of Malta from the Roman period to the Middle Ages, unpublished $\mathrm{PhD}$, University of Bristol, Bristol, 2005.

Gambin, T.: A drop in the ocean - Malta's trade in olive oil during the Roman periods, in: The Zejtun Roman Villa, edited by: Ruben Abela, Wirt Iz-Zejtun, Malta, 2012.

Gelorini, V., Ssemmanda, I., and Verschuren, D.: Validation of nonpollen palynomorphs as paleoenvironmental indicators in tropical Africa?: contrasting 200-year paleolimnological records of climate change and human impact, Rev. Palaeobot. Palyno., 186, 90-101, doi:10.1016/j.revpalbo.2012.05.006, 2012.

Giesecke, T., Bennett, K. D., Birks, H. J. B., Bjune, A. E., Bozilova, E., Feurdean, A., Finsinger, W., Froyd, C., Pokorný, P., Rösch, M., Seppä, H., Tonkov, S., Valsecchi, V., and Wolters, S.: The pace of Holocene vegetation change - testing for synchronous developments, Quaternary Sci. Rev., 30, 28052814, doi:10.1016/j.quascirev.2011.06.014, 2011. 
Giorgi, F. and Lionello, P.: Climate change projections for the Mediterranean region, Global Planet. Change, 63, 90-104, doi:10.1016/j.gloplacha.2007.09.005, 2008.

Gladich, I., Gallai, I., Giaiotti, D. B., Mordacchini, Gp., Palzzo, A., and Stel, F.: Mesoscale heat waves induced by orography, Adv. Sci. Res., 2, 139-143, 2008.

Grech, C. F.: A forest history of the Maltese Islands, unpublished $\mathrm{PhD}$, University of Aberdeen, Aberdeen, 2001.

Grigore, M. and Toma, C.: Ecological anatomy of halophyte species from the Chenopodiaceae family, 4th WSEAS International Conference on Mathematical Biology and Ecology (MABE'08) Acapulco, Mexico, 25-27 January, 62-67, 2008.

Grimm, E. C.: TILIA and TGView software, version 2.0.2, Illinois State University, Springfield, 14 USA, 2004/5.

Grove, A. T. and Rackham, O.: The Nature of Mediterranean Europe: An Ecological History, Yale University Press, London, 2001.

Guiot, J.: Methodology of the last climatic cycle reconstruction in France from pollen data, Palaeogeogr. Palaeocl., 80, 49-69, 1990.

Haas, J.-N.: Palaeoecological indicators found in pollen preparations from Holocene freshwater lake sediments, Rev. Palaeobot. Palyno., 91, 371-382, 1996.

Hajar, L., Haïdar-Boustani, M., Khater, C., and Cheddadi, R.: Environmental changes in Lebanon during the Holocene: man vs. climate impacts, J. Arid Environ., 74, 746-755, doi:10.1016/j.jaridenv.2008.11.002, 2010.

Hall, S. J., Trujillo, J., Nakase, D., Strawhacker, C., KrusePeeples, M., Schaafsma, H., and Briggs, J.: Legacies of prehistoric agricultural practices within plant soil properties across an arid ecosystem, Ecosystems, 16, 1273-1293, doi:10.1007/s10021-013-9681-0, 2013.

Havinga, A.: An experimental investigation into the decay of pollen and spores in various soil types, in: Sporopollenin, edited by: Brooks, J., Grant, P. R., Muir, M. D., Van Gijzel, P., and Shaw, G., Academic Press, New York, 446-479, 1971.

Hevly, R. H.: Pollen production, transport and preservation: potentials and limitations in archeological palynology, J. Ethnobiol., 1, 39-54, 1981.

Hjelle, K. L.: Herb pollen representation in surface moss samples from mown meadows and pastures in western Norway, Veg. Hist. Archaeobot., 7, 79-96, doi:10.1007/BF01373926, 1998.

Hjelle, K. L.: Use of modern pollen samples and estimated pollen representation factors as aids in the interpretation of cultural activity in local pollen diagrams, Nor. Archaeol. Rev., 32, 19-39, doi:10.1080/002936599420885, 1999.

Hughes, K. J.: Persistent features from a palaeo-landscape: the ancient tracks of the Maltese Islands, Geogr. J., 165, 1, 62-78, doi:10.2307/3060511, 1999.

Hunt, C. O.: Quaternary deposits in the Maltese Islands: a microcosm of environmental change in Mediterranean lands, Geogr. J., 41, 101-109, 1997.

Hunt, C. O., Gilbertson, D. D., and El-Rishi, H. A.: An 8000-year history of landscape, climate, and copper exploitation in the Middle East: the Wadi Faynan and the Wadi Dana National Reserve in southern Jordan, J. Archaeol. Sci., 34, 1306-1338, 2007.

Hunt, C. O.: Palynology of some archaeological deposits from TasSilq, in: Tas-Silg, Marsaxlokk (Malta) I: Archaeological Excavations Conducted by the University of Malta, 1996-2005, edited by: Bonanno, A. and Vella, N. C., Ancient Near Eastern Studies Supplement Series, 48, Peeters Publishing, Leuven, 2015.

Jahns, S.: A late Holocene pollen diagram from the Megaris, Greece, giving possible evidence for cultivation of Ceratonia siliqua L. during the last 2000 years, Veg. Hist. Archaeobot., 12, 127-130, doi:10.1007/s00334-003-0013-8, 2003.

Jahns, S.: The Holocene history of vegetation and settlement at the coastal site of Lake Voulkaria in Acarnania, western Greece, Veg. Hist. Archaeobot., 14, 55-66, doi:10.1007/s00334-004-0053-8, 2005.

Jalut, G., Dedoubat, J. J., Fontugne, M., and Otto, T.: Holocene circum-Mediterranean vegetation changes: climate forcing and human impact, Quatern. Int., 200, 4-18, doi:10.1016/j.quaint.2008.03.012, 2009.

Joannin, S., Brugiapaglia, E., Beaulieu, J.-L., Bernardo, L., Magny, M., Peyron, O., Goring, S., and Vannière, B.: Pollenbased reconstruction of Holocene vegetation and climate in southern Italy: the case of Lago Trifoglietti, Clim. Past, 8, 1973 1996, doi:10.5194/cp-8-1973-2012, 2012.

Kaniewski, D., Van Campo, E., Boiv, T., Terral, J. F., Khadari, B., and Besnard, G.: Primary domestication and early uses of the emblematic olive tree: palaeobotantical, historical and molecular evidences from the Middle East, Biol. Rev., 87, 885-899, 2012.

Kaniewski, D., Van Campo, E., Morhange, C., Guiot, J., Zuiely, D., Le Burel, S., Otto, T., and Artzy, M.: Mediterranean ecosystems to long term changes along the coast of Israel, PLoS ONE, 9, e102090, doi:10.1371/journal.pone.0102090, 2014.

Kotthoff, U., Pross, J., Müller, U. C., Peyron, O., Schmiedl, G., Schulz, H., and Bordon, A.: Climate dynamics in the borderlands of the Aegean Sea during formation of sapropel S1 deduced from a marine pollen record, Quaternary Sci. Rev., 27, 832-845, doi:10.1016/j.quascirev.2007.12.001, 2008.

Kotthoff, U., Koutsodendris, A., Pross, J., Schmiedl, G., Bornemann, A., Kaul, C., Marino, G., Peyron, O., and Schiebel, R.: Impact of Lateglacial cold events on the northern Aegean region reconstructed from marine and terrestrial proxy data, J. Quaternary Sci., 26, 86-96, doi:10.1002/jqs.1430, 2011.

Kouli, K., Gogou, A., Bouloubassi, I., Triantaphyllou, M. V., Ioakim, C., Katsouras, G., Roussakis, G., and Lykousis, V.: Late postglacial paleoenvironmental change in the northeastern Mediterranean region: Combined palynological and molecular biomarker evidence, Quaternary Int., 261, 118-127, 2012.

Li, Y., Zhou, L., and Cui, H.: Pollen indicators of human activity, Chinese Sci. Bull., 53, 1281-1293, doi:10.1007/s11434-0080181-0, 2008.

Lionello, P., Malanotte-Rizzoli, P., and Boscolo, R.: Mediterranean Climate Variability, Elsevier B. V., Amsterdam, 2006.

Litt, T., Ohlwein, C., Neumann, F. H., Hense, A., and Stein, M.: Holocene climate variability in the Levant from the Dead Sea pollen record, Quaternary Sci. Rev., 49, 95-105, doi:10.1016/j.quascirev.2012.06.012, 2012.

Locatelli, D.: The Roman Villa at San Pawl Milqi: history and perspectives of an archaeological site, Treasures of Malta, 7, 73-79, 2001.

López-Sáez, J. A. López Garcia, P., and Sánchez, M. M.: Palaeoecology and Holocene environmental change from a saline lake in south-west Spain: protohistorical and prehistorical vegetation in Cadiz Bay, Quatern. Int., 94, 197-206, 2002. 
López-Merino, L., Cortizas, A. M., and López-Sáez, J. A.: Early agriculture and palaeoenvironmental history in the north of the Iberian Peninsula: a multi-proxy analysis of the Monte Areo mire (Asturias, Spain), J. Archaeol. Sci., 37, 1978-1988, doi:10.1016/j.jas.2010.03.003, 2010.

MacDonald, G. M. and Cwynar, L. C.: A fossil pollen based reconstruction oft he late Quaternary history of lodgepole pine (Pinus contorta spp. latifolia) in the western interior of Canada, Can. J. Forest Res., 15, 1039-1044, 1985.

MacDonald, G. M. and Edwards, K. J.: Holocene palynology: I. Principles, population and community ecology, palaeoclimatology, Prog. Phys. Geog., 15, 261-289, doi:10.1177/030913339101500303, 1991.

Macphail, M. and Stevenson, J.: Fungal Spores in Archaeologocal Contexts: Part 1 Background Evidence, CAR, Canberra, 2004.

Magny, M. and Combourieu Nebout, N.: Holocene changes in environment and climate in the central Mediterranean as reflected by lake and marine records, Clim. Past, 9, 1447-1454, doi:10.5194/cp-9-1447-2013, 2013.

Magny, M., Miramont, C., and Sivan, O.: Assessment of the impact of climate and anthropogenic factors on Holocene Mediterranean vegetation in Europe on the basis of palaeohydrological records, Palaeogeogr. Palaeocl., 186, 47-59, doi:10.1016/S00310182(02)00442-X, 2002.

Magny, M., de Beaulieu, J. L., Drescher-Schneider, R., Vannière,B., Walter-Simonnet, A. V., Miras, Y., Millet, L., Bossuet, G., Peyron, O., Brugiapaglia, E., and Leroux, A.: Holocene climate changes in the central Mediterranean as recorded by lake-level fluctuations at Lake Accesa (Tuscany, Italy), Quaternary Sci. Rev., 26, 1736-1758, 2007.

Magny, M., Vannière, B., Zanchetta, G., Fouache, E., Touchais, G., Petrika, L., Coussot, C., Walter-Simonnet, A.-V., and Arnaud, F.: Possible complexity of the climatic event around 4300-3800 cal. BP in the central and western Mediterranean, Holocene, 19, 823-833, doi:10.1177/0959683609337360, 2009.

Magny, M., Vannière, B., Calo, C., Millet, L., Leroux, A., Peyron, O., Zanchetta, G., La Mantia, T., and Tinner, W.: Holocene hydrological changes in south-western Mediterranean as recorded by lake-level fluctuations at Lago Preola, a coastal lake in southern Sicily, Italy, Quaternary Sci. Rev., 30, 24592475, 2011

Magny, M., Peyron, O., Sadori, L., Ortu, E., Zanchetta, G., Vannière, B., and Tinner, W.: Contrasting patterns of precipitation seasonality during the Holocene in the south- and north-central Mediterranean, J. Quaternary Sci., 27, 290-296, 2012.

Markgraf, V. and Kenny, R.: Character of rapid vegetation and cliamte change during the late-glacial in southernmost South America, in: Past and Future Rapid Environmental Changes: The Spatial and Evolutionary Responses of Terrestrial Biota, edited by: Huntley, B., Cramer, W., Morgan, A. V., Prentice, H. C., and Allen, J. R. M., Springer-Verlag, Berlin, 1997.

Marriner, N., Gambin, T., Djamali, M., Morhange, C., and Spiteri, M.: Geoarchaeology of the Burmarrad ria and early Holocene human impacts in western Malta, Palaeogeogr. Palaeocl., 339-341, 52-65, doi:10.1016/j.palaeo.2012.04.022, 2012.

Mauri, A., Davis, B. A. S., Collins, P. M., and Kaplan, J. O.: The climate of Europe during the Holocene: a gridded pollen-based reconstruction and its multi-proxy evaluation, Quaternary Sci. Rev., 112, 109-127, doi:10.1016/j.quascirev.2015.01.013, 2015.

Mayewski, P. A., Rohling, E. J., Curtstager, J., Karlen, W., Maasch, K., Davidmeeker, L., Meyerson, E., Gasse, F., Vankreveld, S., and Holmgren, K.: Holocene climate variability, Quaternary Res., 62, 3, 243-255, doi:10.1016/j.yqres.2004.07.001, 2004.

Mazier, F., Galop, D., Brun, C., and Buttler, A.: Modern pollen assemblages from grazed vegetation in the western Pyrenees, France: a numerical tool for more precise reconstruction of past cultural landscapes, Holocene, 16, 91-103, doi:10.1191/0959683606hl908rp, 2006.

Médail, F. and Quézel, P.: Biodiversity hotspots in the Mediterranean Basin: setting global conservation priorities, Conserv. Biol., 13, 1510-1513, doi:10.1046/j.1523-1739.1999.98467.x, 1999.

Mercuri, A. M.: Genesis and evolution of the cultural landscape in central Mediterranean: the "where, when and how" through the palynological approach, Landsc. Ecol., 29, 1799-1810, 2014.

Mercuri, A. M., Accorsi, C. A., Mazzanti, M. B., Bosi, G., Cardarelli, A., Labate, D., Marchesini, M., and Grandi, G. T.: Economy and environment of Bronze Age settlements - Terramaras on the Po Plain (Northern Italy): first results from the archaeobotanical research at the Terramara di Montale, Veg. Hist. Archaeobot., 16, 43-60, doi:10.1007/s00334-006-0034-1, 2006.

Mercuri, A. M., Sadori, L., and Uzquiano Ollero, P.: Mediterranean and north-African cultural adaptations to mid-Holocene environmental and climatic changes, Holocene, 21, 189-206, 2011.

Mercuri, A. M., Bandini Mazzanti, M., Florenzano, A., Montecchi, M., Rattighieri, E., and Torri, P.: Anthropogenic Pollen Indicators (API) from archaeological sites as local evidence of human-induced environments in the Italian Peninsula, Ann. Bot., 3, 143-153, doi:10.4462/annbotrm-10316, $2013 \mathrm{a}$.

Mercuri, A. M., Bandini Mazzanti, M., Florenzano, A., Montecchi, M. C., and Rattighieri, E.: Olea, Juglans and Castanea: the OJC group as pollen evidence of the development of humaninduced environments in the Italian peninsula, Quat. Int., 303, 24-42, 2013b.

Mercuri, A. M., Allevato, E., Arobba, D., Bandini Mazzanti, M., Bosi, G., Caramiello, R., Castiglioni, E., Carra, M. L., Celant, A., Costantini, L., Di Pasquale, G., Fiorentino, G., Florenzano, A., Guido, M., Marchesini, M., Mariotti Lippi, M., Marvelli, S., Miola, A., Montanari, C., Nisbet, R., Peña-Chocarro, L., Perego, R., Ravazzi, C., Rottoli, M., Sadori, L., Ucchesu, M., and Rinaldi, R.: Pollen and macroremains from Holocene archaeological sites: a dataset for the understanding of the biocultural diversity of the Italian landscape, Rev. Palaeobot. Palynol., 218, 250-326, 2015.

Metcalfe, C. R.: Report on the botanical determination of charcoal samples, in: Skorba: Excavations Carried Out on Behalf of the National Museum of Malta, 1961-1963. Reports of the Research Committee of the Society of Antiquaries of London, Appendix V, edited by: Trump, D. H., The Society of Antiquaries, London and the National Museum of Malta, London, 1966.

Moore, P. D., Webb, J. A., and Collinson, M. E.: Pollen Analysis, 2nd edn., Blackwell, Oxford, 1991.

Morley, A., Rosenthal, Y., and DeMenocal, P.: Ocean-atmosphere climate shift during the mid-to-late Holocene transition, Earth 
Planet. Sc. Lett., 388, 18-26, doi:10.1016/j.epsl.2013.11.039, 2014.

Mottershead, D., Pearson, A., and Schaefer, M.: The cart ruts of Malta: an applied geomorphology approach, Antiquity, 82, 1065-1079, 2007.

Mudie, P. J., Leroy, S. A. G., Marret, F., Gerasimenko, N., Kholeif, S. E. A, Sapelko, T., and Filipova-Marinova, M.: Nonpollen palynomorphs: indicators of salinity and environmental change in the Caspian-Black Sea-Mediterranean corridor, Geol. S. Am. S., 473, 1-27, 2011.

Noti, R., Leeuwen, J. F. N., Colombaroli, D., Vescovi, E., Pasta, S., Mantia, T., and Tinner, W.: Mid- and late-Holocene vegetation and fire history at Biviere di Gela, a coastal lake in southern Sicily, Italy, Veg. Hist. Archaeobot., 18, 371-387, doi:10.1007/s00334-009-0211-0, 2009.

Pace, A.: The building of megalithic Malta, in: Malta before History, edited by: Cilia, D., Miranda Books, Malta, 2004.

Pantaléon-Cano, J., Yll, E.-I., Pérez-Obiol, R., and Roure, J. M.: Palynological evidence for vegetational history in semi-arid areas of the western Mediterranean (Almería, Spain), Holocene, 13, 109-119, doi:10.1191/0959683603hl598rp, 2003.

Pavlopoulos, K., Triantaphyllou, M., Karkanas, P., Kouli, K., Syrides, G., Vouvalidis, K., Palyvos, N., and Tsourou, T.: Paleoenvironmental evolution and prehistoric human environment, in the embayment of Palamari (Skyros Island, Greece) during Middle-Late Holocene, Quatern. Int., 216, 41-53, doi:10.1016/j.quaint.2009.08.015, 2010.

Pedley, H. M., Hughes Clarke, M., and Galea, P.: Limestone Isles in a Crystal Sea, The Geology of the Maltese Islands, Publishers Enterprises Group, Malta, 2002.

Pérez-Obiol, R. and Sadori, L.: Similarities and dissimilarities, synchronisms and diachronisms in the Holocene vegetation history of the Balearic Islands and Sicily, Veg. Hist. Archaeobot., 16, 259-265, doi:10.1007/s00334-006-0038-x, 2007.

Pérez-Obiol, R., Jalut, G., Julia, R., Pelachs, A., Iriarte, M. J., Otto, T., and Hernandez-Beloqui, B.: Mid-Holocene vegetation and climatic history of the Iberian Peninsula, Holocene, 21, 7593, doi:10.1177/0959683610384161, 2011.

Peyron, O., Goring, S., Dormoy, I., Kotthoff, U., Pross, J., Beaulieu, J.-L., Drescher-Schneider, R., Vannière, B., and Magny, M.: Holocene seasonality changes in the central Mediterranean region reconstructed from the pollen sequences of Lake Accesa (Italy) and Tenaghi Philippon (Greece), Holocene, 21, 131-146, doi:10.1177/0959683610384162, 2011.

Peyron, O., Magny, M., Goring, S., Joannin, S., Beaulieu, J.-L., Brugiapaglia, E., Sadori, L., Garfi, G., Kouli, K., Ioakim, C., and Combourieu Nebout, N.: Contrasting patterns of climatic changes during the Holocene across the Italian Peninsula reconstructed from pollen data, Clim. Past, 9, 1233-1252, doi:10.5194/cp-9-1233-2013, 2013.

Pons, A. and Quézel, P.: The history of the flora and vegetation and past and present human disturbance in the Mediterranean region, in: Plant conservation in the Mediterranean area, edited by: Gomez-Campo, C., Dr. W. Junk Publisher, Dordrecht, 25-43, 1985.

Pross, J., Kotthoff, U., Müller, U. C., Peyron, O., Dormoy, I., Schmiedl, G., Kalaitzidis, S., and Smith, A. M.: Massive perturbation in terrestrial ecosystems of the Eastern Mediterranean region associated with the $8.2 \mathrm{kyr}$ climatic event, Geology, 37, 887-890, 2009.

Pyankov, V. I., Gunin, P. D., Tsoog, S., and Black, C. C.: C 4 plants in the vegetation of Mongolia: their natural occurrence and geographical distribution in relation to climate, Oecologia, 123, 1531, doi:10.1007/s004420050985, 2000.

Reille, M.: Pollen et spores d'Europe et d'Afrique du Nord, Laboratoire de botanique historique et de palynologie, Marseille, 1992.

Reille, M.: Pollen et spores d'Europe et d'Afrique du Nord, Laboratoire de botanique historique et de palynologie - Suppl 1, Marseille, 1995.

Reille, M.: Pollen et spores d'Europe et d'Afrique du Nord, Laboratoire de botanique historique et de palynologie - Suppl 2, Marseille, 1998.

Reimer, P. J., Baillie, M. G. L., Bard, E., Bayliss, A., Beck, J. W., Blackwell, P. G., Bronk Ramsey, C., Buck, C. E., Burr, G., Edwards, R. L., Friedrich, M., Grootes, P. M., Guilderson, T. P., Hajdas, I., Heaton, T. J., Hogg, A. G., Hughen, K. A., Kaiser, K. F., Kromer, B., McCormac, F. G., Manning, S. W., Reimer, R. W., Richards, D. A., Southon, J., Turney, C. S. M., van der Plicht, J., and Weyhenmeyer, C.: IntCal09 and Marine09 radiocarbon age calibration curves, 0-50,000 years cal BP, Radiocarbon, 51, 1111-1150, 2009.

Roberts, N.: The Holocene: An Environmental History, 3rd edn., Wiley-Blackwell, Chichester, 2014.

Roberts, N., Brayshaw, D., Kuzucuoglu, C., Perez, R., and Sadori, L.: The mid-Holocene climatic transition in the Mediterranean: causes and consequences, Holocene, 21, 3-13, doi:10.1177/0959683610388058, 2011.

Sadori, L. and Giardini, M.: Charcoal analysis, a method to study vegetation and climate of the Holocene: the case of Lago di Pergusa (Sicily, Italy), Geobios, 40, 173-180, doi:10.1016/j.geobios.2006.04.002, 2007.

Sadori, L., Giraudi, C., Petitti, P., and Ramrath, A.: Human impact at Lago di Mezzano (central Italy) during the Bronze Age: a multidisciplinary approach, Quatern. Int., 113, 5-17, 2004.

Sadori, L., Jahns, S., and Peyron, O.: Mid-Holocene vegetation history of the central Mediterranean, Holocene, 21, 117-129, doi:10.1177/0959683610377530, 2011.

Sadori, L., Bertini, A., Combourieu Nebout, N., Kouli, K., Mariotti Lippi, M., Roberts, N., and Mercuri, A. M.: Palynology and Mediterranean vegetation history, Flora Mediterr., 23, 141-156, doi:10.7320/FlMedit23.141, 2013a.

Sadori, L., Ortu, E., Peyron, O., Zanchetta, G., Vannière, B., Desmet, M., and Magny, M.: The last 7 millennia of vegetation and climate changes at Lago di Pergusa (central Sicily, Italy), Clim. Past, 9, 1969-1984, doi:10.5194/cp-9-1969-2013, 2013 b.

Sadori, L., Masi, A., and Ricotta, C.: Climate driven past fires in central Sicily, Plant Biosyst., 149, 166-173, 2015 a.

Sadori, L., Giraudi, C., Masi, A., Magny, M., Ortu, E., Zanchetta, G., and Izdebski, A.: Climate, environment and society in southern Italy during the last 2000 years, A review of the environmental, historical and archaeological evidence, Quat. Sci. Rev., doi:10.1016/j.quascirev.2015.09.020, online first, 2015b.

Schembri, P. J.: The Maltese Islands: climate, vegetation and landscape, GeoJournal, 41, 2, 115-125, 1997.

Sharifi, A., Pourmand, A., Canuel, E. A., Ferer-Tyler, E., Peterson, L. C., Aichner, B., Feakins, S. J., Daryaee, T., Djamali, M., Naderi, A., Lahijani, H. A. K., and Swart, P. K.: Abrupt climate 
variability since the last deglaciation based on a high-resolution, multi-proxy peat record from NW Iran: the hand that rocked the Cradle of Civilization?, Quaternary Sci. Rev., 123, 215-230, 2015.

Sotillo, M. G., Ramis, C., Romero, R., Alonso, S., and Homar, V.: Role of orography in the spatial distribution of precipitation over the Spanish Mediterranean zone, Clim. Res., 23, 247-261, doi:10.3354/cr023247, 2003.

Steans, S.C.: Life-history tactics: a review of the ideas, Q. Rev. Biol., 51, 3-47, 1976.

Stevens, D. T., Lanfranco, E., Mallia, A., and Schembri, P. J.: Biodiversity conservation and utilisation in the Maltese Islands, in: Monitoring Biodiversity, Developing Island States, Malta, Report, Commonwealth Science Council Conference on Identifying and Monitoring Biodiversity and its Utilization in Commonwealth Small Island Developing States, Valletta, Malta, 1995.

Stevenson, A. D.: Pollen studies in semi-arid areas: north east Iran and south west Spain, unpublished PhD, King's College University, London, 1981.

Stockmarr, J.: Tablets with spores used in absolute pollen analysis, Pollen et Spores, 13, 615-621, 1971.

Ter Braak, C. J. F. and Juggins, S.: Weighted averaging partial least squares regression (WA-PLS): an improved method for reconstructing environmental variables from species assemblages, Hydrobiologia, 269/270, 485-502, 1993.

Ter Braak, C. J. F. and van Dam, H.: Inferring pH from diatoms: a comparison of old and new calibration methods, Hydrobiologia, 178, 209-223, 1989.

Tinner, W., van Leeuwen, J. F. N., Colombaroli, D., Vescovi, E., van der Knaap, W. O., Henne, P. D., Pasta, S., D'Angelo, S., and La Mantia, T.: Holocene environmental and climatic changes at Gorgo Basso, a coastal lake in southern Sicily, Italy, Quaternary Sci. Rev., 28, 1498-1510, doi:10.1016/j.quascirev.2009.02.001, 2009.

Traverse, A.: Paleopalynology, 2nd Edn., Springer, the Netherlands, 2008.

Trump, D. H.: Malta: An Archaeological Guide, Faber and Faber, London, 1972.

Trump, D. H.: Malta: Prehistory and Temples, Midsea Books, Malta, 2002.

Trump, D. H.: Dating Malta's prehistory, in: Malta before History, edited by: Cilia, D., Miranda Books, Malta, 2004.

Van Geel, B.: A palaeoecological study of Holocene peat bog sections in Germany and the Netherlands, based on the analysis of pollen, spores and macro- and microscopic remains of fungi, algae, cormophytes and animals, Rev. Palaeobot. Palyno., 25, 1$120,1978$.

Van Groenendael, J. M.: Life history characteristics of two ecotypes of Plantago lanceolata L., Acta Bot. Neerl., 35, 71-86, 1986.
Vannière, B., Power, M. J., Roberts, N., Tinner, W., Carrión, J., Magny, M., Bartlein, P., Colombaroli, D., Daniau, A. L., Finsinger, W., Gil-Romera, G., Kaltenrieder, P., Pini, R., Sadori, L., Turner, R., Valsecchi, V., and Vescovi, E.: Circum-Mediterranean fire activity and climate changes during the mid-Holocene environmental transition (8500-2500 cal BP), Holocene, 21, 53-73, doi:10.1177/0959683610384164, 2011.

Van Overloop, E.: Comparison of climatic evolution during postglacial times in Greece, tropical an subtropical regions, in relation to desertification, in: Desertification in Europe, Symposium on Climatology, Mytilene, Greece, 15-18 April 1984, D. Reidel Publishing, 59-72, 1986.

van Zeist, W. and Bottema, S.: Late Quaternary Vegetation of the Near East, Beihefte zum Tubinger Atlas des Vorderen Orients: Reihe A, Naturwissenschaften 18, Reichet, Wiesbaden, 1991.

van Zeist, W., Baruch, U., and Bottema, S.: Holocene palaeoecology of the Hula area, northeastern Israel, in: A Timeless Vale. Archaeological and Related Essays on the Jordan Valley in Honour of Gerrit Van Der Kooij on the Occasion of his Sixty-Fifth Birthday, edited by: Kaptijn, K. and Petit, L. P., Leiden University Press, Leiden, 29-64, 2009.

Walsh, K.: The Archaeology of Mediterranean Landscapes: Human-Environment Interaction from the Neolithic to the Roman Period, Cambridge University Press, Cambridge, 387 pp., 2013.

Warny, S., Jarzen, D. M., Evans, A., Hesp, P., and Bart, P.: Environmental significance of abundant and diverse hornwort spores in a potential submerged Paleoindian site in the Gulf of Mexico, Palynology, 36, 234-253, doi:10.1080/01916122.2012.666507, 2012.

Weiner, S.: Microarchaeology, Beyond the Visible Archaeological Record, Cambridge University Press, Cambridge, 2010.

Weiss, H. and Bradley, R. S.: What drives societal collapse?, Science, 80, 609-610, doi:10.1126/science.1058775, 2001.

Wells, H. G.: A Short History of the World, Macmillan Publishers, New York, 1922.

Wilson, A.: The Mediterranean environment in ancient history: perspectives and prospects, in: The Ancient Mediterranean Environment between Science and History, edited by: Harris, W. V., Brill, Lieder Boston, 2013.

Zanchetta, G., Bini, M., Cremaschi, M., Magny, M., and Sadori, L.: The transition from natural to anthropogenic-dominated environmental change in Italy and the surrounding regions since the Neolithic: An introduction, Quat. Int., 303, 1-9, 2013.

Zielhofer, C. and Faust, D.: Mid- and Late Holocene fluvial chronology of Tunisia, Quat. Sci. Rev., 27, 580-588, 2008. 